Version of the attached file: Non-peer reviewed preprint submitted to EarthArxiv Peer-reviewed status of the attached file: Non-peer reviewed

Citation for the pre-print file: Chowdhury, M.K., K.M. Konsoer, and M. Hiatt (2020), Effect of lateral outflow on three-dimensional flow structure in a river delta, EarthArxiv.

Additional information: This manuscript is a preprint and has been submitted to the Journal of Geophysical Research: Earth Surface for publication. The manuscript version posted on EarthArxiv is non-peer reviewed and subsequent versions of the manuscript may differ slightly from this version. If the manuscript is accepted for publication, the final typeset version will be available via the "Peer-reviewed Publication DOI" link on the right hand side of the web page. Please feel free to contact any of the authors, we welcome feedback. 


\title{
EFFECT OF LATERAL OUTFLOW ON THREE-DIMENSIONAL FLOW STRUCTURE IN A RIVER DELTA
}

\author{
Mohammad Kifayath Chowdhury ${ }^{1}$, Kory M Konsoer ${ }^{2,3}$, Matthew Hiatt ${ }^{1,3}$ \\ ${ }^{1}$ Department of Oceanography and Coastal Sciences, College of the Coast and Environment, Louisiana \\ State University, Baton Rouge, LA, USA \\ ${ }^{2}$ Department of Geography, Louisiana State University, Baton Rouge, LA, USA \\ ${ }^{3}$ Coastal Studies Institute, Louisiana State University, Baton Rouge, LA, USA
}

\section{Key Points:}

- Channelized outflow was observed to produce coherent secondary circulations while unchannelized lateral outflow did not.

- Formation of coherent secondary circulation may depend upon available lateral momentum flux in the channel.

- Lateral momentum flux in the distributary channels may control the sediment transport mechanism in a deltaic system.

Corresponding author: Matthew Hiatt, mhiatt1@lsu.edu 


\begin{abstract}
Spatial and temporal patterns in three-dimensional flow structure have been linked to channel processes and morphology in many environments, including river meander bends, confluences-diffluences, and bedrock canyons. However, there is not yet an understanding of how channelized and gradually distributed lateral outflows that are often prevalent in river deltas influence three-dimensional flow structure and sediment transport mechanisms. This study presents an analysis of 3D flow structure data collected from Wax Lake Delta, a naturally developing river-dominated delta in the northern Gulf of Mexico. Three hydrographic surveys were conducted using a boat-mounted acoustic Doppler current profiler (ADCP) at two sites: a channelized outflow zone and a distributary channel experiencing distributed lateral outflow. The flow structure was analyzed to identify secondary circulation cells induced by lateral outflow, which may influence the sediment transport to the islands. Spatial patterns in flow structure were also compared to previous numerical modeling and experimental studies on open channel diversions and compound channels. A conceptual model is developed linking the formation of secondary circulation cells and suspended sediment transport from the distributary channels to interdistributary islands in a delta. The results suggest that a transition from advective to turbulent diffusion transport mechanism may occur depending upon a threshold outflow momentum flux ratio which lies in between $0.211 \mathrm{~km}^{-1}$ and $0.375 \mathrm{~km}^{-1}$. This study provides the first detailed quantification of flow structure in an actively prograding river delta and offers important implications for coastal restoration by linking coastal sediment transport mechanism to patterns in flow structure.
\end{abstract}

\title{
Plain Language Summary
}

In a river delta, channels lose a significant amount of water to the islands because of lateral discharge through small crevasse and also as overbank. With the water, sediment and nutrients also get carried from the channels into the delta islands. This process supports the deltaic ecosystem and influences the evolution of the delta. Although, it is yet to be shown how such lateral discharge may affect the three dimensional flow field in the delta channels and sediment transport mechanisms. Here we use high resolution three-dimensional velocity data from a river delta to determine the influence of two different outflow processes on the nearby flow field. We observe strong coherent helical circulations in the channels when the lateral outflow is concentrated in a small area (i.e., a side channel) whereas weak transient structures when the lateral discharge gets distributed over a large area (i.e., overbank flow). The results suggest the existence of a threshold outflow momentum that triggers the formation of such coherent helical circulations and induces changes to the sediment transport mechanism. The results of this study have implications for better understanding of delta hydrodynamics and morphological evolution.

\section{Introduction}

Many coastal regions worldwide are currently facing the problem of landloss because of their susceptibility to sea-level rise (SLR) and subsidence. For example, the Mississippi River delta has lost one-third of its wetland area since the European settlement of North America (Day et al., 2000). The situation is further exacerbated by the reduction of sediment supply from upstream due to various river control structures like levees, which have effectively disconnected the river from its wetlands (Paola et al., 2011). Some coastal states, such as Louisiana, have undertaken comprehensive plans (CPRA, 2017) for designing and implementing coastal restoration and protection projects. One proposed solution for the coastal land loss problem is engineered sediment diversions, which are designed to divert sediment and water from the river onto the sediment starved 
delta plain and initiate the formation of deltas by capitalizing on natural land-building processes (Temmerman et al., 2013; Temmerman \& Kirwan, 2015).

Deltaic environments are known to exhibit hydraulic connectivity between distributary channels and interdistributary islands through lateral outflow (Hiatt \& Passalacqua, 2015). For example, at Wax Lake Delta (WLD), Louisiana, nearly $23-54 \%$ of the river water entering the delta is transported to the vegetated island interiors from the channels via overbank flow and flow through secondary channels (Hiatt \& Passalacqua, 2015). This result has been confirmed through numerical modeling (Hiatt \& Passalacqua, 2017) and flow pattern analyses (Shaw et al., 2016). The connectivity is modulated by discharge, tides, and the presence of vegetation (Hiatt \& Passalacqua, 2015, 2017). Besides, the trend of velocity and sediment transport in the lowermost reaches of rivers are significantly modulated by the discharge lost through outflow (Esposito et al., 2020). The transition between the channelized zones upstream and unchannelized delta front is also known to control the morphodynamic evolution of a river delta (Shaw et al., 2016; Coffey \& Shaw, 2017). Analyzing the three-dimensional flow structure in these outflow zones of such "leaky networks" (Passalacqua, 2017) and linking them to the existing literature of delta morphology thus can yield a comprehensive understanding into the natural land building processes.

Flow structure provides information regarding the interaction of primary and secondary components of velocity. The primary velocity component points in the direction of bulk flow whereas the secondary components are those superimposed on the primary, usually with a velocity that is at least an order of magnitude lower than the primary (Citerone, 2016). These secondary components develop turbulent structures driven by the anisotropy and inhomogeneity of turbulence (Nezu \& Onitsuka, 2001; Tominaga \& Nezu, 1991) and can be categorized as either coherent or incoherent based on their period of existence. A turbulent structure is coherent if it is present in the flow for a relatively long time whereas incoherent structures are transient phenomena. Coherent turbulent structures can significantly influence a system by entraining sediment particles and carrying them in suspension (Dwivedi et al., 2011). Field measurements and numerical modeling have been used to analyze flow structure in different fluvial systems like meander bends (Engel \& Rhoads, 2017; Frothingham \& Rhoads, 2003; Konsoer et al., 2016; Sukhodolov, 2012; Zinger et al., 2013), confluences (Lane et al., 2000; Miyawaki et al., 2010; Rhoads \& Kenworthy, 1998; Serres et al., 1999; Szupiany et al., 2009), bifurcations (Hardy et al., 2011; Marra et al., 2014), and bedrock canyons (Venditti et al., 2014). Though field measurements, remote sensing, and numerical modeling have highlighted the two-dimensional transport processes in prograding deltas like WLD (Hiatt \& Passalacqua, 2017; Shaw et al., 2018), there remains a lack of synoptic field measurements of flow structure resulting from channelized and unchannelized lateral outflow from distributary channels. The current study aims to fill this gap through field measurements in a prograding delta.

When lateral discharge from a distributary channel occurs through a secondary channel or crevasse, it is defined as channelized lateral outflow (CO). One system analogous to CO is an open channel diversion. Bulle (1926) first observed that secondary flow induced by a diversion causes a nonlinear distribution of sediment to be transported into the lateral channel. Later, secondary circulation cells have been observed in both the main and lateral channels of $90^{\circ}$ diversion systems (Dutta et al., 2016, 2017; Herrero et al., 2015; Neary \& Odgaard, 1993; Neary et al., 1999; Ramamurthy et al., 2007). Prior analyses have shown that the skew-induced vorticity caused by an imbalance between the transverse pressure gradient, shear, and centrifugal forces, is the primary source of secondary circulation cells at a diversion (Neary \& Odgaard, 1995). For a $90^{\circ}$ diversion on the left side of the main channel, two circulation cells have been identified, one rotating clockwise inside the lateral channel and another rotating counterclockwise located downstream of the diversion in the main channel (Neary \& Odgaard, 1993). A relationship between the strength of secondary circulation downstream of the diversion and momentum flux 
associated with the lateral outflow was proposed by Herrero et al. (2015). While progress has been made, there remains a lack of analyses on the effects of upstream separation on secondary circulation at diversions.

Nearly all of the $90^{\circ}$ diversion studies focus on systems where the main and lateral channels have the same bed elevation (Bulle, 1926; Dutta et al., 2017; Neary \& Odgaard, 1993; Ramamurthy et al., 2007). An example of a discordant (i.e. difference in bed elevation between the main and lateral channel) flow system is a side weir where channel bedform morphology has been observed to be impacted by the lateral outflow through the weir (Michelazzo et al., 2016; Paris et al., 2012; Rosier et al., 2011). 3-D eddies forming at the side weirs divert sediment into the weirs and the efficiency of the transport process is dependent on turbulent intensity in the main channel, local bed morphology, and weir geometry (Michelazzo et al., 2016). The side weirs resemble many natural systems that often exhibit bed discordance, especially in the transition from main channels to floodplains and small crevasses.

An outflow process is defined as unchannelized (UO) when the lateral discharge flows over the channel levees. UO in the subaqueous parts of the delta is analogous to the compound channel flow studied in fluvial settings. The characteristics of compound channel flow structure are recognized by the flow specifically in the junction between main channel and flood plain (Tominaga \& Nezu, 1991). There have been several experimental (Azevedo et al., 2017; Nezu \& Onitsuka, 2001; Proust \& Nikora, 2019; Shiono \& Knight, 1991; Tominaga \& Nezu, 1991; Yang et al., 2007; Zeng et al., 2016) and simulation studies (Cokljat \& Younis, 1995; Kang \& Choi, 2006; Naot et al., 1993, 1996; Sofialidis \& Prinos, 1999; van Prooijen et al., 2005) on turbulent flow structures and momentum exchange for compound channels with and without vegetation. For Froude number ranging from 0.312-0.415, Tominaga and Nezu (1991) observed a pair of longitudinal vortices both on the sides of main channel and floodplain with secondary velocity $4 \%$ of the primary velocity, and the vortex size appeared to be affected by the depth ratio between the floodplain and main channel. Secondary current intensity and turbulent energy at the junction increases with increasing Froude number and vegetation (Nezu \& Onitsuka, 2001). The existence of horizontal coherent structures caused by Kelvin-Helmholtz instability (KHCS) formed at the interface of low flow on the flood plain and high flow in the main channel, may also play a significant role in the lateral momentum exchange in compound channels (Nezu \& Onitsuka, 2001; van Prooijen et al., 2005). Additionally, the direction of transverse currents was found to be a crucial control over the orientation of secondary flow structures in compound channels (Proust \& Nikora, 2019).

As sediment is transported from channels to islands through UO, natural levees form at island edges (Adams et al., 2004; Branß et al., 2016). Morphological studies of levees in WLD have shown gently sloped and widespread natural levees (Bevington \& Twilley, 2018) in the downstream parts of the delta. In these unconfined zones, turbulent mixing is minimal (Shaw et al., 2016) and a water-level gradient exists between the interdistributary islands and channels (Hiatt \& Passalacqua, 2017). Based on these features, there is the potential for advective transport of sediment into the island (Adams et al., 2004; Shaw et al., 2016). However, steep levees have also been observed at WLD (Bevington \& Twilley, 2018), which is indicative of transport through turbulent diffusion (Adams et al., 2004). Under what condition the transport mechanism in the unconfined zone switches is still an open question.

The current study analyzes the 3-D flow structure induced by lateral outflow from delta distributary channels and establishes a conceptual model relating the flow structure and sediment transport mechanisms. The research addresses the following questions: (1) How does lateral outflow affect the three-dimensional flow structure within delta distributary channels? and (2) Does lateral outflow impact the mechanism of sediment transport from the channel to the island? The results generated by this study have implications for understanding and evaluating hydrodynamics and sediment transport processes 
in deltaic systems, which may be used to evaluate the efficacy of sediment diversions at reproducing the processes of land-building deltas in addition to aiding in design and operation strategies.

\section{Methods}

\subsection{Site Description}

Wax Lake delta (WLD) is a river dominated delta located in coastal Louisiana (Fig. 1) at the mouth of the $25 \mathrm{~km}$ long Wax Lake Outlet (WLO). WLD debouches into the Atchafalaya Bay about $140 \mathrm{~km}$ West-Southwest of New Orleans. The outlet was dredged by US Army Corps of Engineers in 1942 with a design capacity to carry $30 \%$ of the discharge from the Atchafalaya River to reduce flooding in Morgan City, LA (Roberts et al., 2003). Sediment began to deposit at the mouth of WLO immediately after construction and WLD has been steadily prograding since its first subaerial emergence in 1973 (Roberts et al., 1997). Sediment input to WLD is estimated to be $38.4 \mathrm{Mt} /$ year, $18 \%$ of which is sand (Kim et al., 2009). Estimates of the delta land growth rate and the total area of land built provided by the literature are variable but it is estimated that approximately over $100 \mathrm{~km}^{2}$ new deltaic surface has been developed at WLD since its subaerial emergence in 1973 (Roberts, 1998; Wellner et al., 2005). Water-level on this delta is modulated by mixed semidiurnal microtides (mean range of $0.35 \mathrm{~m}$ ) (Hiatt \& Passalacqua, 2015) and the average flow in WLO is $3078 \mathrm{~m}^{3} / \mathrm{s}$ while the annual flood tends to peak above 5000 $\mathrm{m}^{3} / \mathrm{s}$.

WLD is a branching distributary network with seven major channels and partiallyinundated interdistributary islands. The channel network of WLD consists of primary (>100 m width) and lateral secondary channels. Primary channels distribute the discharge and sediment throughout the system and secondary channels connect the primary channels to the island interiors. The delta islands are typically shaped like an arrowhead and are surrounded by narrow levees with higher elevation. The distributary channels are lined with these levees which can be sub-aerial or subaqueous based on the water-level. Flow over the levees resulting in flow exchange between the channels and islands is a persistent feature of the system. The sedimentary framework of WLD is 50-70\% medium sand (Roberts et al., 1997). The $D_{50}$ and $D_{90}$ (50th and 90th percentiles of grain size) at WLD apex are respectively $106 \mu \mathrm{m}$ and $155 \mu \mathrm{m}$ (Shaw et al., 2013). The Froude number of flow entering the delta is $\sim 0.25$ during bankfull flow (Edmonds et al., 2011).

In this study, the flow structure at two channel features in WLD were investigated: $\mathrm{CO}$ and UO along the length of the channel. The CO study site was located at Mallard Pass, a distributary channel in the western part of the delta, $2.3 \mathrm{~km}$ downstream of the channel entrance (Fig. 1b). The secondary channel flowing laterally into the interdistributary island has been stable since 1990 (Wellner et al., 2005). At WLD, UO has been primarily observed along distributary channels near the delta front and generally takes the form of lateral overbank flow (Hiatt \& Passalacqua, 2015; Shaw et al., 2016). To capture this particular phenomenon, a $3.7 \mathrm{~km}$ long section of Gadwall Pass was surveyed in this study (Fig. 1c). 

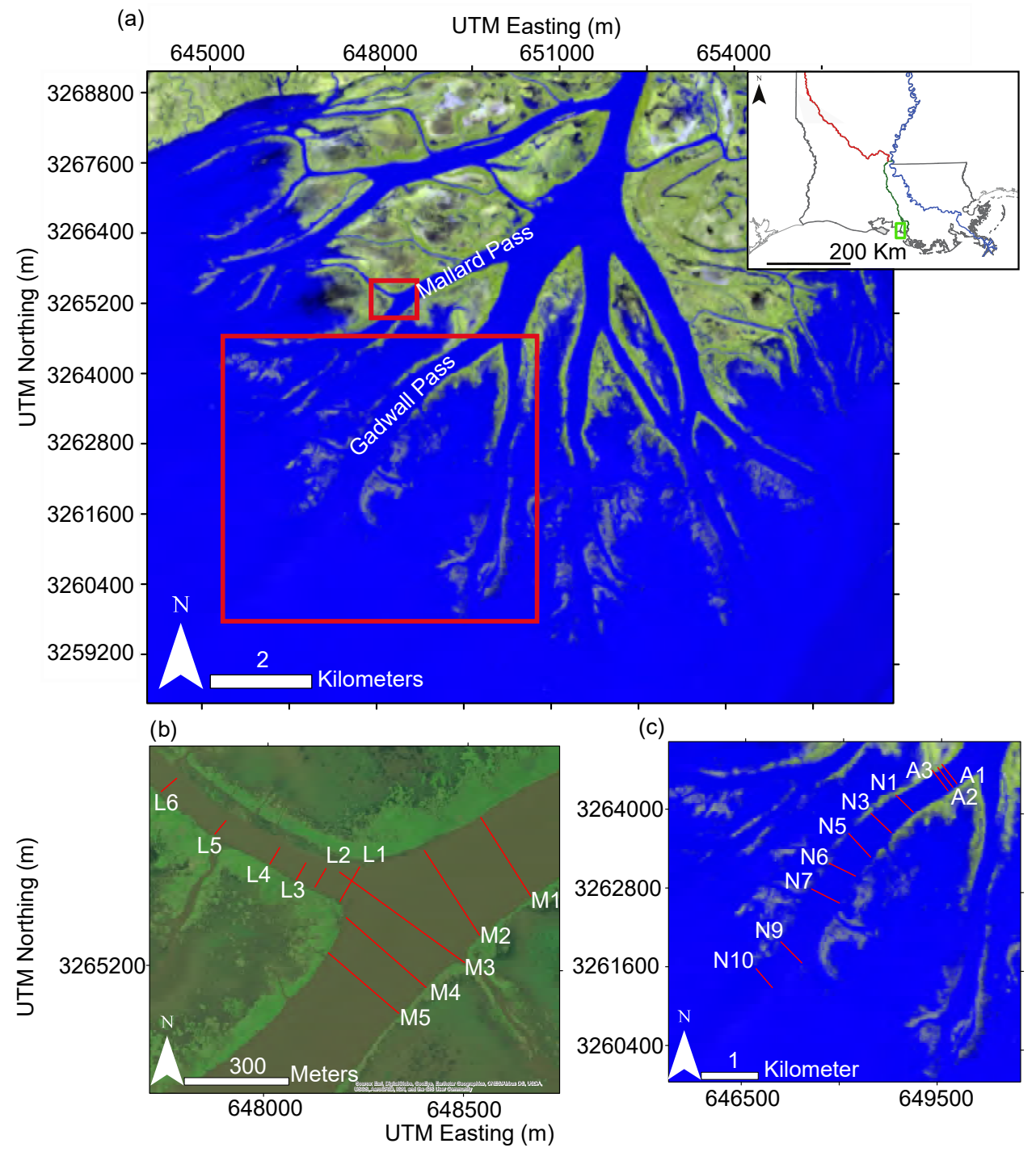

Figure 1. (a) Map of WLD. Locations of ADCP transects traversed in Mallard Pass (15 April and 10 June 2019) and in Gadwall Pass (9 June and 13-14 September 2019) are marked by red rectangles. (b) ADCP transect locations of the channelized outflow system in Mallard Pass. Sources: ArcGIS Online. (c) ADCP transect locations of Gadwall pass. Image specifications of (a) and (c): LANDSAT 8 images from 23 October 2019 at $30 \mathrm{~m}$ resolution obtained from USGS EarthExplorer (available online at https://earthexplorer.usgs.gov/) 


\subsection{Data Collection}

The field measurements at WLD comprised three trips from April 2019 to September 2019. Time series plots of discharge at Wax Lake Outlet (USGS Gauge \# 07381590 in Calumet) and water-level (NOAA Lawma-Amerada Pass station \# 8764227) in the water year 2019 are provided in Fig. 2.

(a)

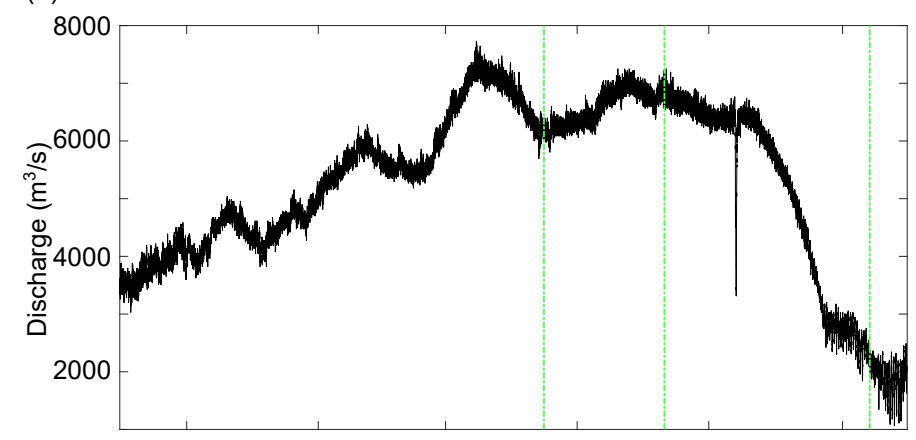

(b)

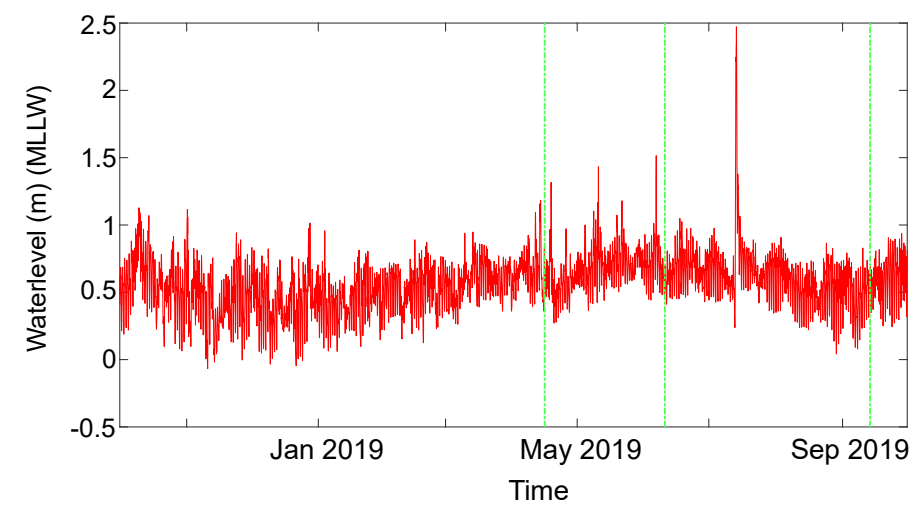

Figure 2. (a) Discharge in the Wax Lake Outlet at the USGS Gauge \# 07381590 in Calumet, LA. (b) Measured water-level at the NOAA Lawma-Amerada Pass station (NOAA \# 8764227) during water year 2019, green verticals indicate survey periods.

A $1200 \mathrm{kHz}$ Teledye RDI RiverPro acoustic Doppler current profiler (ADCP) was used for the hydrographic surveys. All measurements were georeferenced using an external Hemisphere A101 differential Global Positioning System (dGPS) mounted over the ADCP. The ADCP transducer depth was kept at $0.3 \mathrm{~m}$ with a blanking distance of $0.25 \mathrm{~m}$ from the sensor head. Data from the measurement bins close to the bottom were ignored automatically by the ADCP's auto-adaptive system to avoid sidelobe interference. Bin size for each ensemble was optimized by an auto-adaptive system that yielded cell size ranging from $2-24 \mathrm{~cm}$ depending on the depth of that ensemble. The water mode was selected automatically based on the flow condition. The velocity resolution of the ADCP was $1 \mathrm{~mm} / \mathrm{s}$ with an accuracy within $\pm 0.25 \%$ of water velocity relative to the ADCP. At least four repeat transects were performed to collect multiple velocity measurements along the georeferenced cross-sections (Fig. 1) based on community recommendations (Szupiany et al., 2007) and USGS standards for hydrographic surveys (Mueller et al., 2013). When possible, the same georeferenced cross-sections were surveyed during each measurement campaign, but due to the currents and evolving channel planform, slight reorientation of some transects was necessary. 
Velocity and discharge data from the $\mathrm{CO}$ zone were collected during falling tide on 15 April and during rising tide on 10 June 2019. On 15 April (campaign 1), hydrographic measurements were performed at five transects spaced approximately $100 \mathrm{~m}$ apart in the main channel (M1-M5) and at four transects inside the secondary channel separated by approximately $50 \mathrm{~m}$ (L1-L4)(Fig. 1b). The same cross-sections were traversed during the 10 June survey (campaign 2) with two additional transects located further inside the lateral channel. Because of the historic flooding in the lower Mississippi River in 2019 (Pal et al., 2020), the discharge into WLD apex during both the surveys was higher $\left(5584 \mathrm{~m}^{3} / \mathrm{s}\right.$ on 15 April and $5944 \mathrm{~m}^{3} / \mathrm{s}$ on 10 June) than the average in WLO. A discharge summary from the surveys is provided in the supporting information (Table S5).

For the UO site (Fig. 1c), an initial survey of the Gadwall Pass was performed on 9 June 2019 during falling tide to identify the location where lateral outflow begins. Lateral outflow was observed at transect N5 (discharge $1433 \mathrm{~m}^{3} / \mathrm{s}$ ), and it was found to have $\sim 5 \%$ discharge loss relative to the transect $400 \mathrm{~m}$ upstream (transect N3, discharge 1510 $\mathrm{m}^{3} / \mathrm{s}$ )(Table S5, Fig. S2). Thus, N5 represented a reasonable location for the upstream boundary of the lateral outflow zone and was selected as the baseline for the velocity and discharge measurement in September. After the long 2019 flood season (Fig. 2a), the discharge at the delta apex dropped significantly to $2210 \mathrm{~m}^{3} / \mathrm{s}$ in September (Table S5). The cross-sections were spaced $500 \mathrm{~m}$ apart from each other, starting from N5. One initial discharge measurement survey was performed at the beginning of both the 13 and 14 September surveys at the mouth of the Gadwall Pass. During rising tide, 13 September 2019 (campaign 3), 5 of the selected cross-sections (N5-N7, N9-N10) were traversed. On 14 September 2019 (campaign 4), the cross-sections- N5, N9, and N10, were surveyed during falling tide. Transects N7 and N8 from campaign 4 were removed as the discharge variation from each pass of these two transects exceeded acceptable limit. The wind were mostly consistent during the surveys and had a peak speed less than $5 \mathrm{~m} / \mathrm{s}$.

\subsection{Post Processing}

ADCP data were collected, reviewed, and exported as ASCII files using WinRiver $\mathrm{II} \AA$ software. For campaigns 1 and 2 , the beam velocities from WinRiver II $\AA$ were corrected using an in-house code written in Matlab® (Chowdhury, 2020) to account for the effects of tilt, pitch, and roll. Both four-beam and three-beam solutions were taken during the correction (Teledyne, 2010). For campaign 3 and 4, the correction was done using WinRiver II setup wizard with a coordinate transformation user command (Teledyne, 2017). The vertical velocity data from the ADCP was found to be negatively biased and an ensemble mean removal detrending was performed. A comparison between the detrended and biased data is given in the supporting materials (Fig. S1). The corrected data were then analyzed using Velocity Mapping Toolbox (VMT), a suite of Matlab® routines (Parsons et al., 2013). VMT averages the repeat transects along a cross-section, calculates primary and secondary velocity vectors in multiple frames of references for the mean transect, and allows plotting three-dimensional velocity information for the mean cross-section. For this study, the secondary velocity vectors in Rozovskii frame of reference (Rozovskii, 1957) and the transverse vectors were used for interpretation. Secondary vectors in the zero secondary discharge reference frame were ignored as all of the cross-sections traversed in this study had a significant amount of lateral outflow, which violates the assumptions of zero net secondary discharge. In the Rozovskii frame of reference, the secondary vectors are rotated such that for each vertical profile, secondary currents in one direction are equal to those in the opposite direction (Lane et al., 2000). In other words, the primary velocity at each vertical in this reference frame is equivalent to the depth averaged velocity direction at that vertical. Thus the primary velocity direction varies across a section (Lane et al., 2000; Rhoads \& Kenworthy, 1998). The Rozovskii frame of reference is useful to identify helical motion in strongly converging and diverging flows (Rhoads \& Kenworthy, 1998; Rozovskii, 1957). 
The bathymetry data was interpolated from the ADCP transects. For higher resolution bathymetry, additional zigzag ADCP surveys were performed at the field sites to cover more areas along the channel. These bathymetry data were exported using VMT

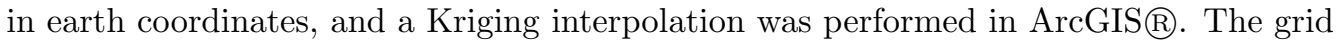
size was $10 \times 10 \mathrm{~m}$ for the CO system and $20 \times 20 \mathrm{~m}$ for the UO sites. The resulting bathymetry was triangulated for visualization in Tecplot 360 (Fig. 3). This method introduces interpolation errors and temporal variation of bed load increases the uncertainty of the resulting spatial distribution (Rennie \& Church, 2010). The interpolated bathymetry here (Fig. 3) is used only for qualitative assessment of the morphology and visualization.

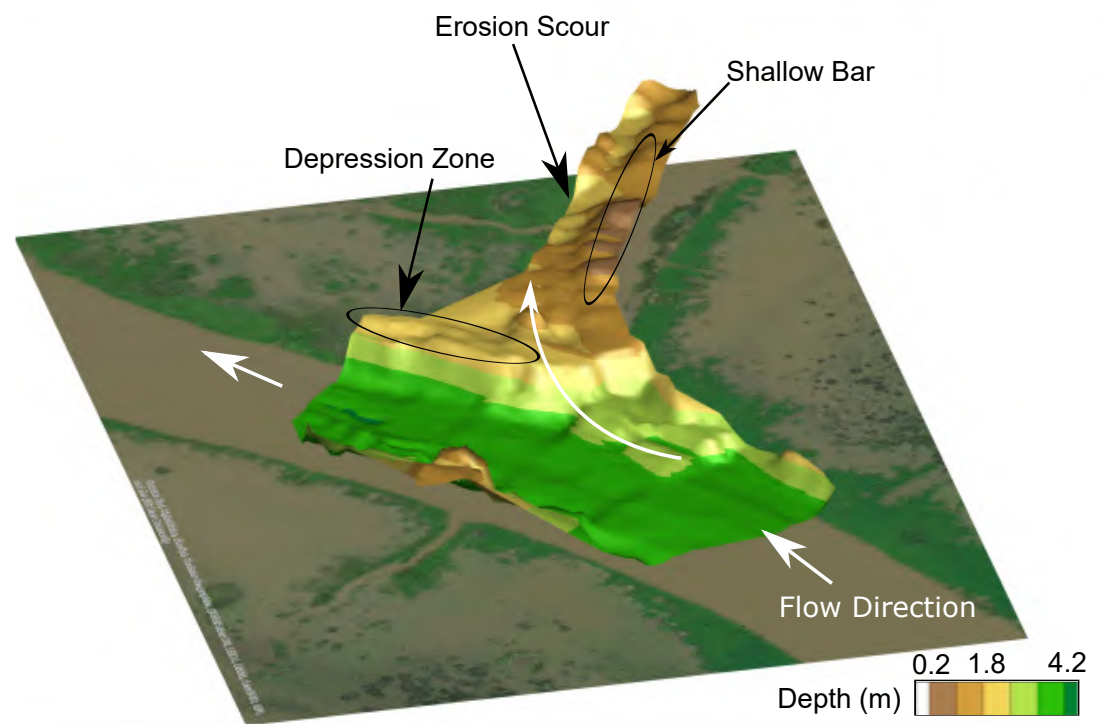

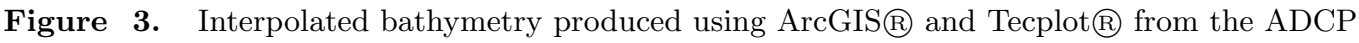
data collected on June 10, 2019. The grid size used for Kriging in ArcGIS® is $10 \mathrm{~m}$.

\subsection{Analysis}

Momentum flux ratio $\left(M_{r}\right)$ is the ratio of momentum flux between two different flows depending on the system being studied. For confluences, $M_{r}$ is defined as the ratio between the momentum fluxes of two incoming channels (Miyawaki et al., 2010). For bifurcations, $M_{r}$ is the ratio of momentum flux between the bifurcating channel and main channel (Herrero et al., 2015). It is calculated as:

$$
M_{r}=\frac{\rho_{l} q_{l} v_{l}}{\rho_{m} q_{m} v_{m}}
$$

which is the ratio of the product of fluid density $(\rho)$, discharge $(q)$, and velocity $(v)$ at the cross section upstream of lateral channel (denoted by subscript $m$ ) and at the mouth of the lateral channel (denoted by subscript $l$ ). $M_{r}$ has been used as a parameter that influences bed morphology and flow pattern in confluences (Miyawaki et al., 2010; Rhoads \& Sukhodolov, 2001) and $90^{\circ}$ diversions (Herrero et al., 2015). The values of $M_{r}$ were calculated for each of the field surveys both on CO and UO systems (Table 1). For this 
study, $\rho_{m}$ and $\rho_{l}$ were assumed to be equal. $q_{m}, v_{m}, q_{l}$, and $v_{l}$ were extracted from the ADCP data (Table 1).

For the purpose of this study, the momentum flux ratio was divided by the length of outflow zone along the primary axis of the main channel to yield momentum flux ratio per unit length of outflow or outflow momentum flux ratio, $M_{r}^{\prime}$. For $\mathrm{CO}$, the length (L) is the lateral channel width. Eq. 1 thus is modified as,

$$
M_{r}^{\prime}=\frac{M_{r}}{L}
$$

For, UO conditions, eq. 2 is modified as the following,

$$
M_{r}^{\prime}=\frac{M_{r l}}{M_{r u} L}
$$

where $M_{r l}$ denotes the momentum flux lost due to lateral outflow for a outflow distance $(\mathrm{L})$. It is calculated by subtracting the momentum flux in the downstream transect $\left(M_{r d}\right)$ from momentum flux in the upstream transect $\left(M_{r u}\right)$. Centerline distance between these transects is used for incremental outflow length $(\mathrm{L})$.

To estimate the sediment entrainment and transport capacity of the secondary circulation, the sediment settling velocity at WLD was calculated using the formula provided by Dietrich (1982).

$$
R_{f}=\frac{v_{s}}{\sqrt{R g D_{50}}}
$$

where $R_{f}$ denotes the dimensionless settling velocity, $\mathrm{g}=9.81 \mathrm{~m} / \mathrm{s}^{2}$ is the gravitational acceleration, and $v_{s}$ is the settling velocity. The submerged specific gravity of sediment $(\mathrm{R})$ is calculated as,

$$
R=\frac{\rho_{s}}{\rho}-1
$$

where $\rho$ the density of fluid (water) and the density of quartz $\left(2.65 \mathrm{~g} / \mathrm{cm}^{3}\right)$ is used as the density of sediment $\left(\rho_{s}\right)$ for this study. $R_{f}$ is calculated using a relationship based on the particle Reynold's number $\left(R e_{p}\right)$ provided in Dietrich (1982). $R e_{p}$ is calculated as,

$$
R e_{p}=\frac{\sqrt{R g D_{50}} D_{50}}{\nu}
$$

where $\nu$ is the kinematic viscosity of water. Here $\nu$ is $8.917 \times 10^{-7} \mathrm{~m}^{2} / \mathrm{s}$ assuming constant water temperature at $25^{\circ} \mathrm{C}$. The median sediment size $D_{50}$ calculated by Shaw et al. (2013) at WLD apex $(106 \mu \mathrm{m})$ was used in this calculation.

\section{Results}

\subsection{Channelized Lateral Outflow}

\section{Discharge and Flow Characteristics}

Depth averaged velocities from the channelized outflow surveys identified spatial gradients in velocity throughout the survey site (Fig. 4). During campaign 1, the discharge $\left(5534 \mathrm{~m}^{3} / \mathrm{s}\right)$ at the delta apex was less than that in campaign $2\left(5943 \mathrm{~m}^{3} / \mathrm{s}\right)$. The lateral channel captured $6.88 \%$ and $5.24 \%$ of the main channel discharge during campaign 1 and campaign 2, respectively (Table 1 ). 
Primary velocity directions for both surveys did not show any significant change with tide. Separation zones upstream of the lateral channel were observed along both banks (Fig. 4). Moreover, the lateral channel bottom was at a higher elevation than the main channel bottom representing a discordant bathymetric feature (Fig. 3). The velocity magnitude into the lateral channel was approximately $50 \%$ of that in the main channel (Table 1). No shallow bar was observed on the opposite bank of the main channel (Fig. 3).

Inside the lateral channel, two zones of flow were observed. The flow close to the right bank (looking downstream) had a significantly lower velocity than the left bank. The high velocity core in the lateral channel shifted from the left bank to the middle of the channel gradually as the water moved further inward (Fig. 4). Additionally, the right bank had a shallow elongated bar, and the left bank was scoured (Fig. 3). During falling tide, velocity downstream of the lateral channel increased and on the other hand decreased during rising tide (Fig. 4). $M_{r}^{\prime}$ for CO varied between $0.375 \mathrm{~km}^{-1}$ and $0.492 \mathrm{~km}^{-1}$, 
(a) Falling Tide

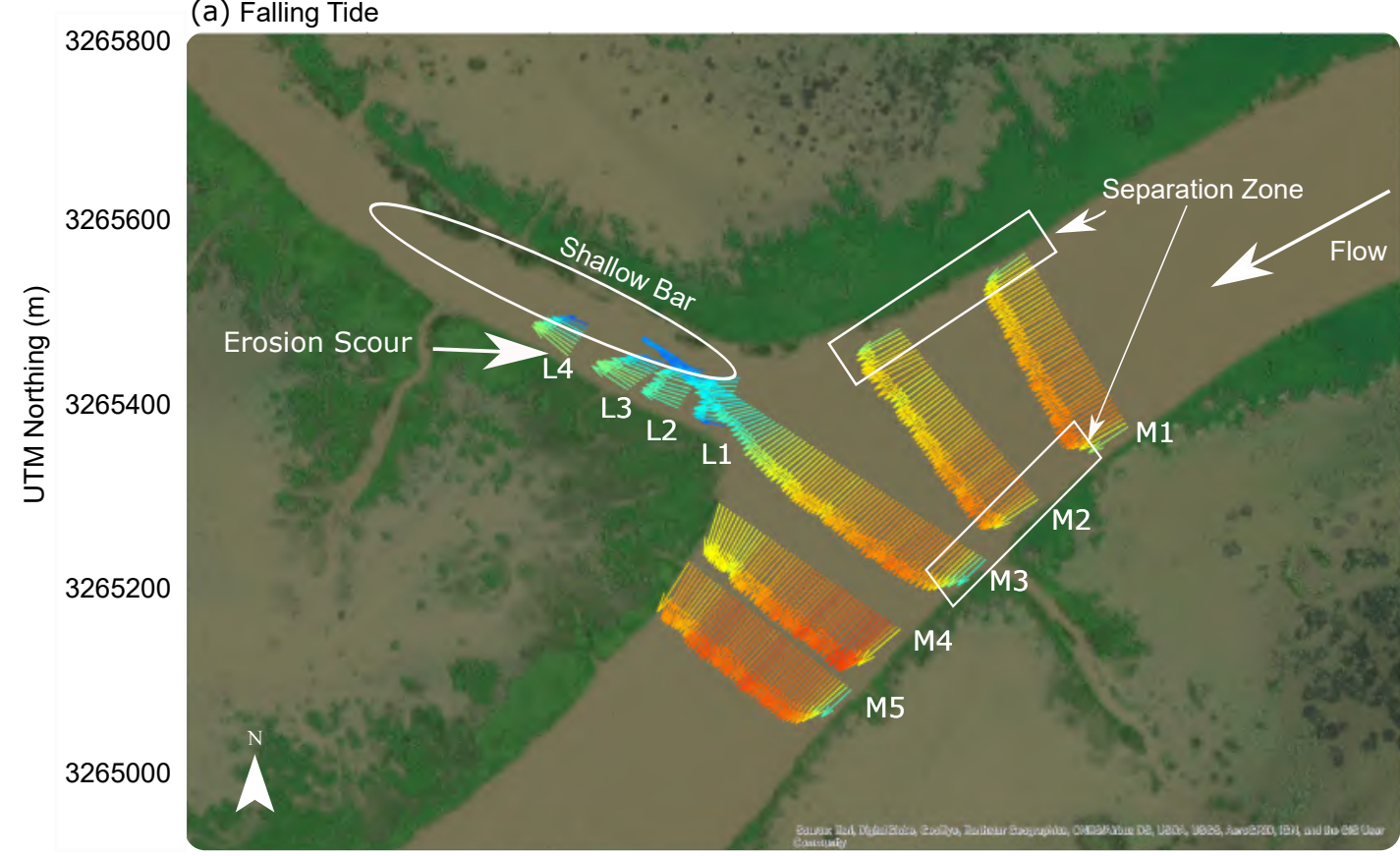

(b) Rising Tide

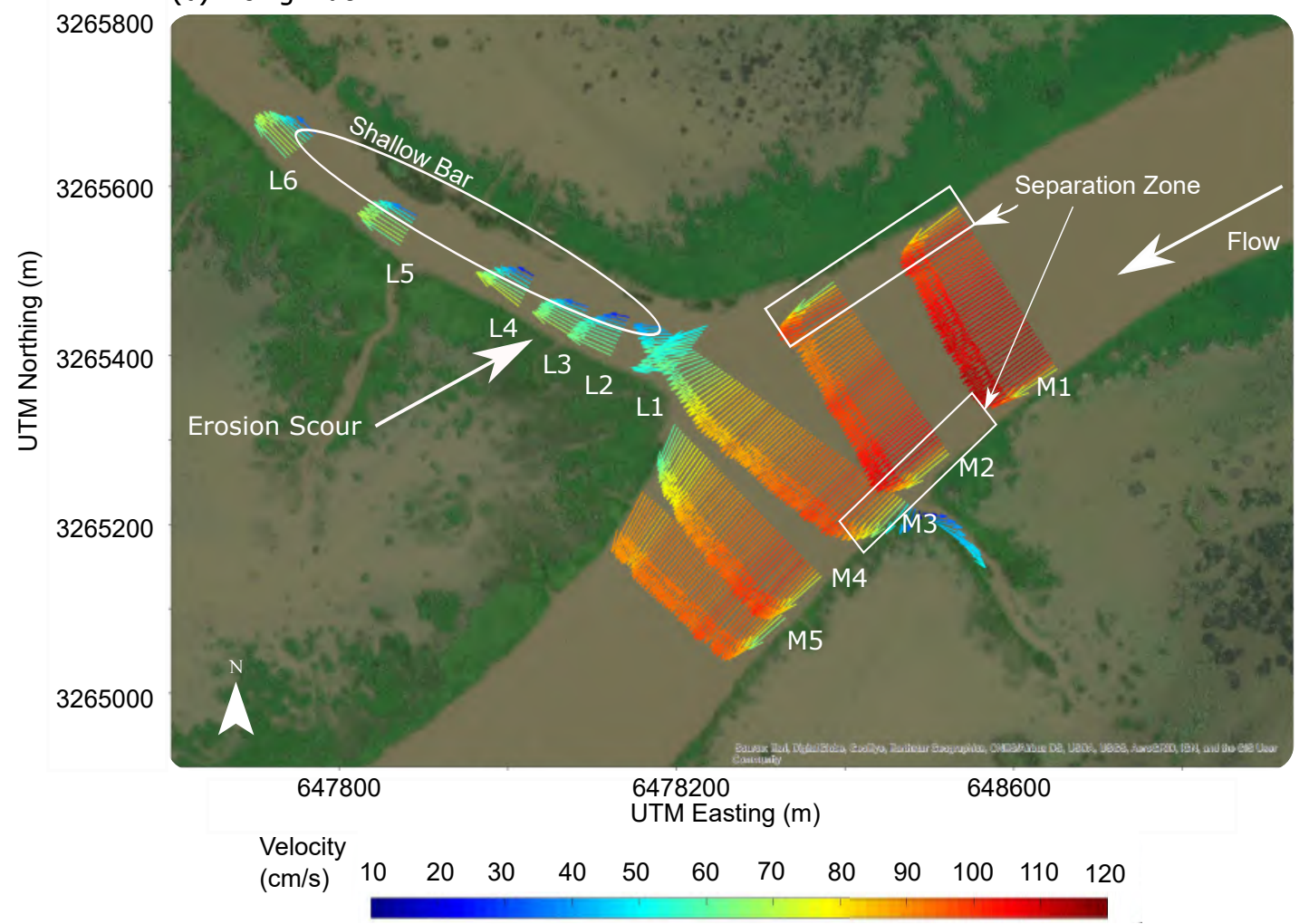

Figure 4. Depth-averaged velocity vectors along the channelized outflow system for (a) campaign 1, 15 April 2019, and (b) campaign 2, 10 June 2019. 
(a)

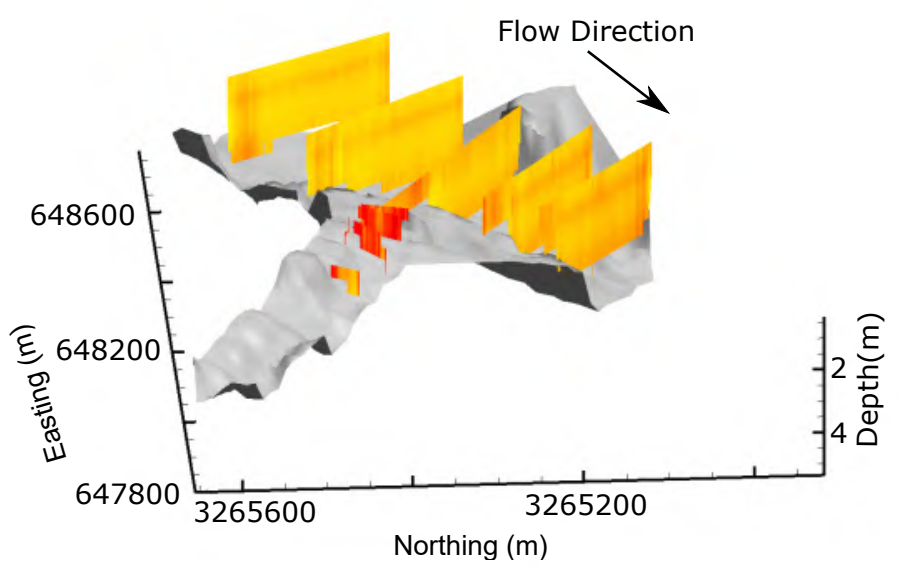

(b)

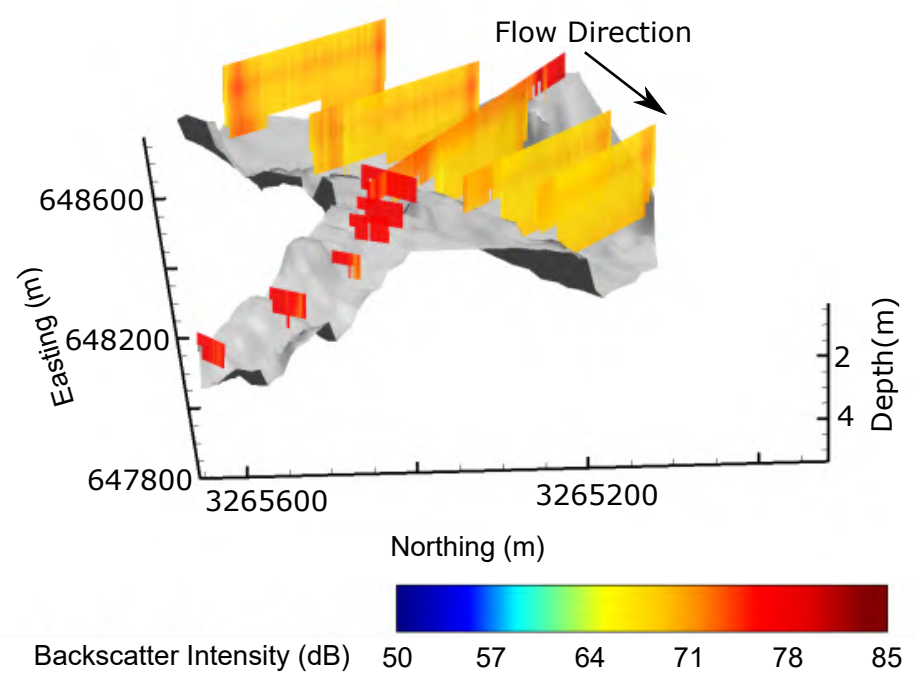

Figure 5. Backscatter intensity for the Channelized Outflow (a) campaign 1, falling tide, 15 April 2019, (b) campaign 2, rising tide, 10 June 2019. Arrows indicate flow direction.

Backscatter intensity was found comparatively higher inside the lateral channel and in the right bank (looking downstream) separation zone both in falling and rising tides (Fig. 5). For the rising tide (Fig. 5b), the intensity was even higher at the discordant crevasse located on the opposite bank. 
Table 1. Channelized Outflow Field Results Summary

\begin{tabular}{|c|c|c|c|}
\hline Parameters & Specification & $\begin{array}{l}\text { Falling Tide } \\
15 \text { April } 2019\end{array}$ & $\begin{array}{l}\text { Rising Tide } \\
\text { 10 June 201 }\end{array}$ \\
\hline \multirow[b]{2}{*}{ Area ratio (Percent) } & $\mathrm{L} 1 / \mathrm{M} 2$ & 12.83 & 13.68 \\
\hline & $\mathrm{L} 1 / \mathrm{M} 4$ & 14.09 & 13.98 \\
\hline \multirow[b]{2}{*}{ Width ratio (Percent) } & L1/M2 & 32.90 & 32.16 \\
\hline & $\mathrm{L} 1 / \mathrm{M} 4$ & 34.01 & 33.96 \\
\hline $\begin{array}{l}\text { Discharge ratio lateral to upstream } \\
\text { (Percent) }\end{array}$ & $\mathrm{L} 1 / \mathrm{M} 2$ & 6.88 & 5.24 \\
\hline $\begin{array}{l}\text { Discharge ratio lateral to down- } \\
\text { stream (Percent) }\end{array}$ & $\mathrm{L} 1 / \mathrm{M} 4$ & 7.10 & 5.80 \\
\hline \multirow{3}{*}{ Width/Depth } & L1 & 50.49 & 53.25 \\
\hline & M2 & 66.72 & 74.30 \\
\hline & M4 & 69.09 & 69.65 \\
\hline \multirow{3}{*}{ Mean velocity magnitude $(\mathrm{cm} / \mathrm{s})$} & L1 & 53.30 & 59.73 \\
\hline & M2 & 90.70 & 109.25 \\
\hline & M4 & 96.64 & 102.66 \\
\hline \multirow{6}{*}{ Lateral channel distance/width ratio } & L1 & 0.37 & 0.17 \\
\hline & $\mathrm{L} 2$ & 0.86 & 1.15 \\
\hline & L3 & 1.47 & 1.70 \\
\hline & L4 & 2.47 & 2.64 \\
\hline & L5 & - & 4.47 \\
\hline & L6 & - & 6.33 \\
\hline \multirow{3}{*}{ Froude Number } & L1 & 0.131 & 0.151 \\
\hline & M2 & 0.147 & 0.185 \\
\hline & M4 & o.162 & 0.173 \\
\hline Momentum flux ratio & & 0.04 & 0.03 \\
\hline $\begin{array}{l}\text { Outflow momentum flux ratio } \\
\left(\mathrm{km}^{-1}\right)\end{array}$ & & 0.492 & 0.375 \\
\hline
\end{tabular}



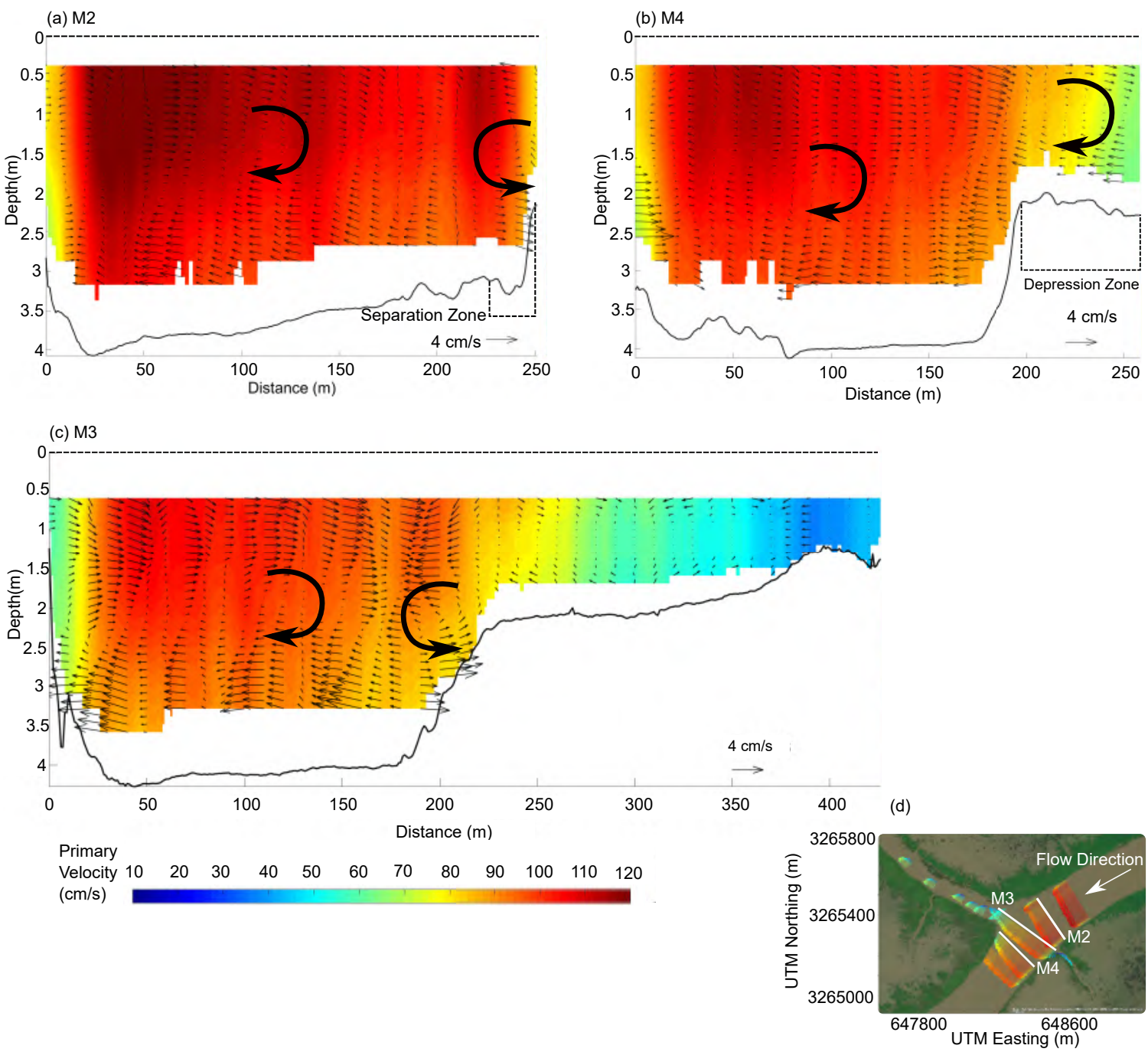

Figure 6. Flow structure at (a) transect M2 upstream of the lateral channel, (b) transect M4, and (c) transect M3 looking downstream. The contour shows the primary velocity in the downstream direction and secondary velocities in Rozovskii reference frame are shown by arrows. Transects M2 and M4 are from campaign 2 (rising tide) and transect M3 data is from campaign 1 (falling tide). The inset shows the location of the transects.

The dominant channel-wide clockwise secondary circulation also prevailed through the transects M4 (Fig. 6b) and M5 (Fig. 7a and 7c). This observed clockwise cell thus extends from upstream M2 to the downstream M5 transect, which is longer than 50 flow 
depths (a channel width). Additionally, a clockwise secondary circulation can also be observed in the depression zone of M4 (Fig. 6b and S3a). At transect M5, a counter-clockwise cell was observed in the depression zone during falling tide (Fig. 7a), whereas a clockwise cell was observed there during rising tide (Fig. 7c). Large transverse current towards the main channel from the island was observed both at M4 (Fig. S3d) and M5 (Fig. 7d) during campaign 2 compared to the smaller transverse current from the same direction during campaign 1 (Fig. S3b and 7b). 
(a)

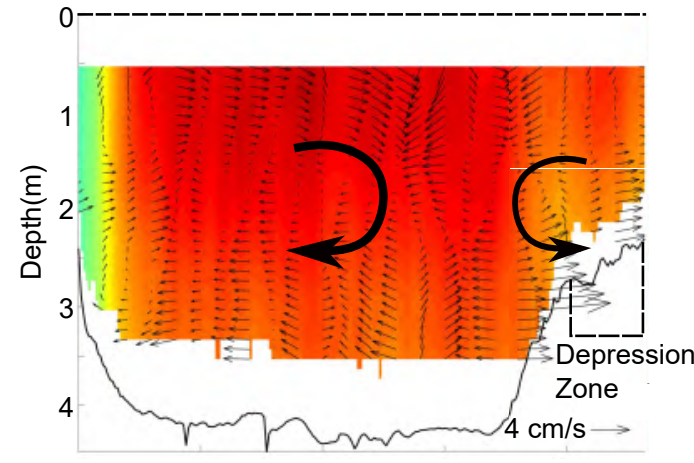

(c)

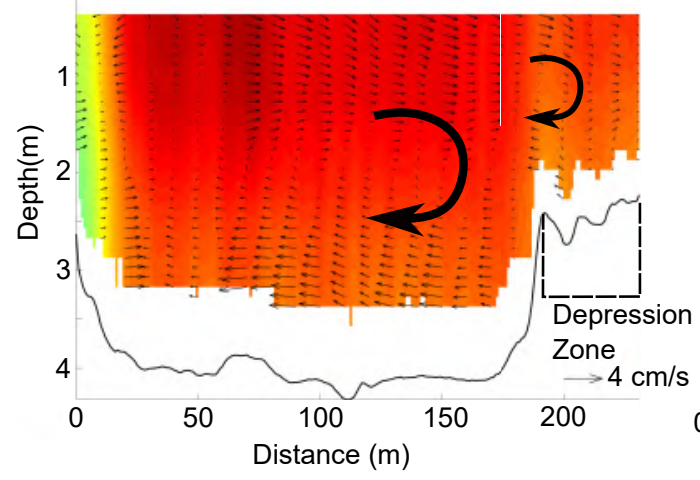

(b)

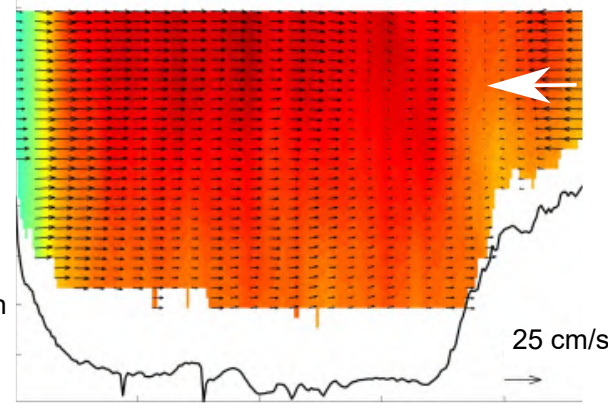

(d)

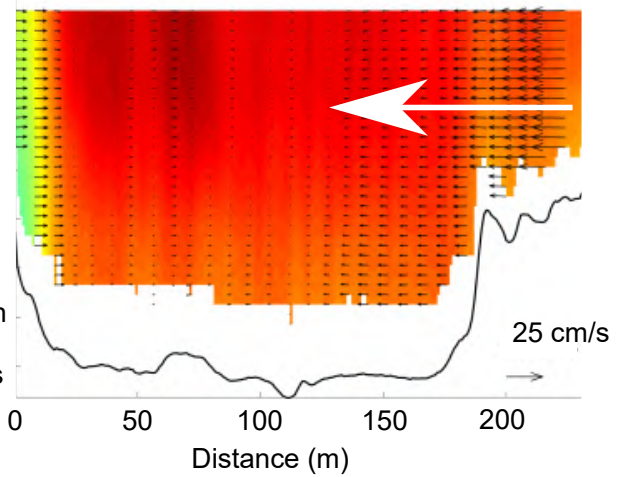

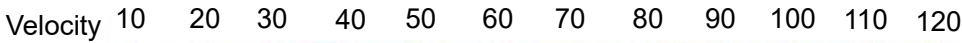
$(\mathrm{cm} / \mathrm{s})$

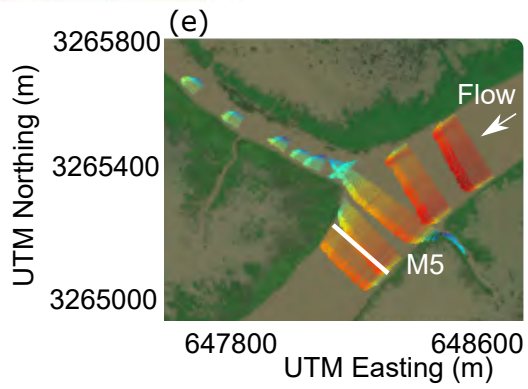

Figure 7. Flow structure and transverse velocity at transect M5, downstream of the lateral channel (looking downstream). The secondary velocities in Rozovskii reference frame are shown by arrows and Rozovskii primary velocities as contour in (a) and (c) respectively from campaign 1 (falling tide) and campaign 2 (rising tide). The transverse velocities with stream-wise velocities as contour from campaign 1 and 2 are presented in (b) and (d), respectively. The inset shows the location of the transect. 
Inside the lateral channel, a coherent counter-clockwise rotating circulation cell (looking downstream) was identified for transects L3-L4 during both campaigns (Fig. 8a and b). A clear separation between the slower flow along the right bank and faster flow along the left bank was observed. This counter-clockwise rotating cell had a helical velocity approaching $3 \mathrm{~cm} / \mathrm{s}$ which was comparatively weaker than that observed in the main channel, and approximately $5 \%$ of the primary velocity. Further inside the lateral channel, the coherent counterclockwise rotating flow structure started to break down (Fig. 8c) as the depth gradually decreased and the high-velocity core, along with the channel thalweg, moved to the center of the lateral channel. In the rising tide survey, the circulation cell was observed to break down inside the channel at a distance of 2.6-4.5 lateral channel widths (Table 1). 
(b) L4

(a) L3
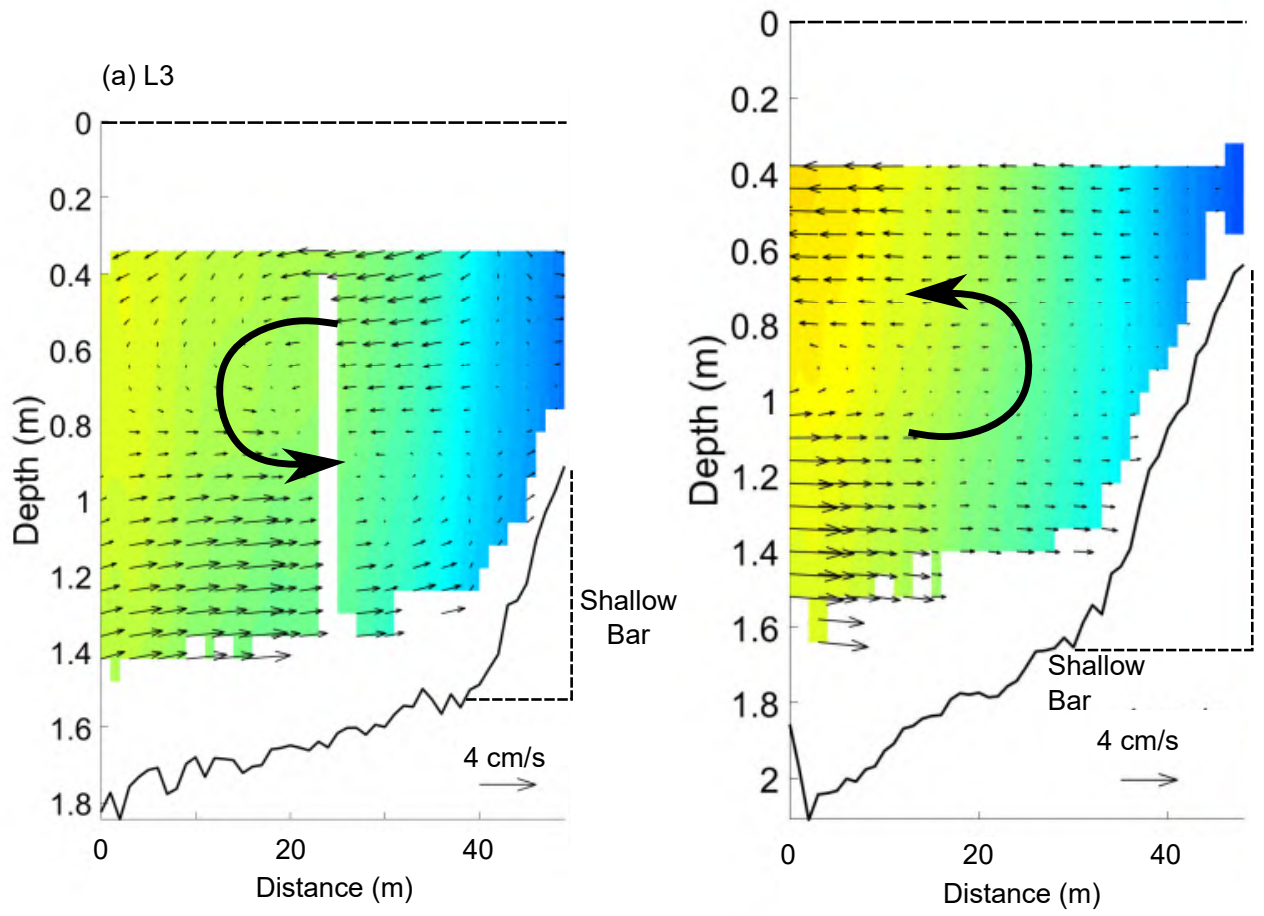

(c) L6

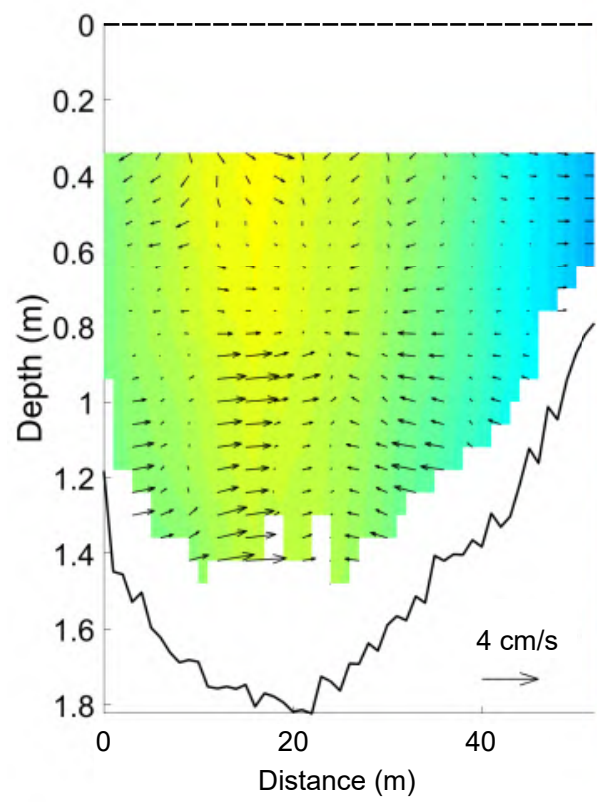

(d)

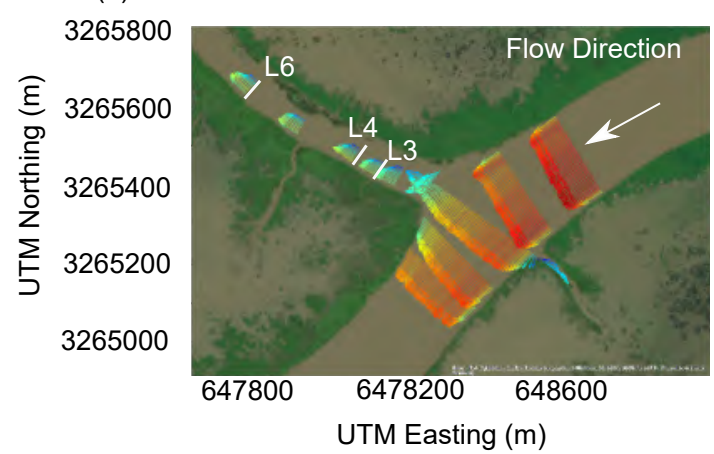

Primary

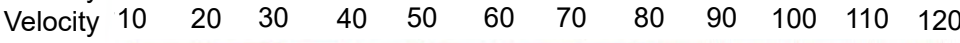
$(\mathrm{cm} / \mathrm{s})$

Figure 8. Flow structure at (a) transect L3, (b) transect L4, and (c) transect L6 into the lateral channel (looking downstream). The contour shows the primary velocity and secondary velocities are shown by arrows in the Rozovskii reference frame. The velocity data was collected during campaign 2. The inset shows the location of the transects. 


\subsection{Unchannelized Lateral Outflow}

\section{Discharge and Flow Characteristics}

Discharge at the upstream end of Gadwall Pass during campaign 3 was $388 \mathrm{~m}^{3} / \mathrm{s}$, which gradually decreased downstream. At transects N9 and N10, the average discharge was $229 \mathrm{~m}^{3} / \mathrm{s}$ and $168 \mathrm{~m}^{3} / \mathrm{s}$, respectively. This represents a discharge loss of $37 \%$ and $54 \%$ relative to the upstream end, respectively. During campaign 4 , the upstream discharge was higher $\left(522 \mathrm{~m}^{3} / \mathrm{s}\right)$ and the trend was similar until transect N10. At N10 (500 m downstream of N9) the discharge $\left(361 \mathrm{~m}^{3} / \mathrm{s}\right)$ was anomalously higher than that of N9 $\left(278 \mathrm{~m}^{3} / \mathrm{s}\right)$. A possible explanation for the increase in discharge at N10 is a lateral flux of water coming to the distributary channel near the transect from the inundated island regions due to tidal factors. The lateral outflow volume at N9 was $30 \%$ of that of N5 during campaign 4. A discharge summary for UO surveys is provided in the supporting information (Fig. S2).

The average velocity at Gadwall Pass during campaign 3 was significantly lower as a consequence of smaller discharge through the channel compared to campaigns 1 and 2. During the rising tide, there was an increase in velocity near transect N7 relative to N5 (Fig. 9a). This increase might be attributed to the interaction with subaqueous channels near the transect location. The velocity core visible at the right bank of N7 gradually disappeared at transect N10, which lost $54 \%$ of flow due to significant lateral outflow. During campaign 4 (Fig. 9b), the high-velocity core strengthened at N10 and moved towards the left bank. During campaigns 3 and 4, the Froude numbers at transect N9 were 0.031 and 0.042 , respectively, and at N5 were 0.038 and 0.046 , respectively. $M_{r}^{\prime}$ for outflow from transect N5 to N9, varied between $0.177 \mathrm{~km}^{-1}$ and $0.211 \mathrm{~km}^{-1}$ and for N5 to $\mathrm{N} 10$ on campaign 3 was, $0.218 \mathrm{~km}^{-1}$. 
(a) Rising Tide

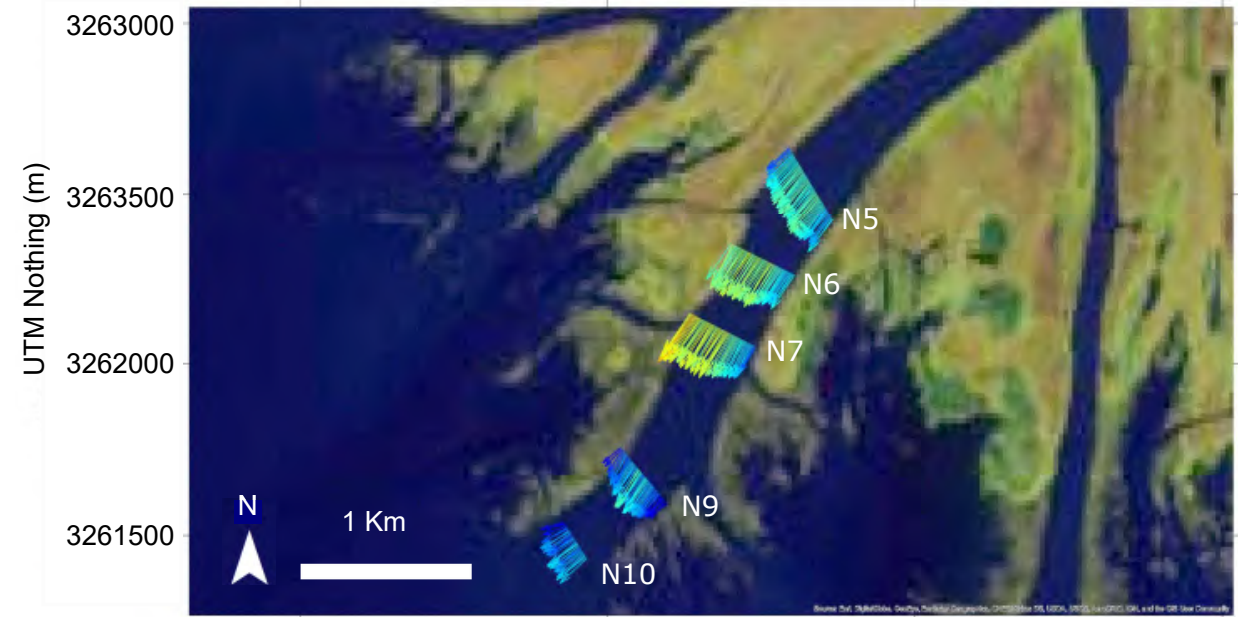

(b) Faling Tide
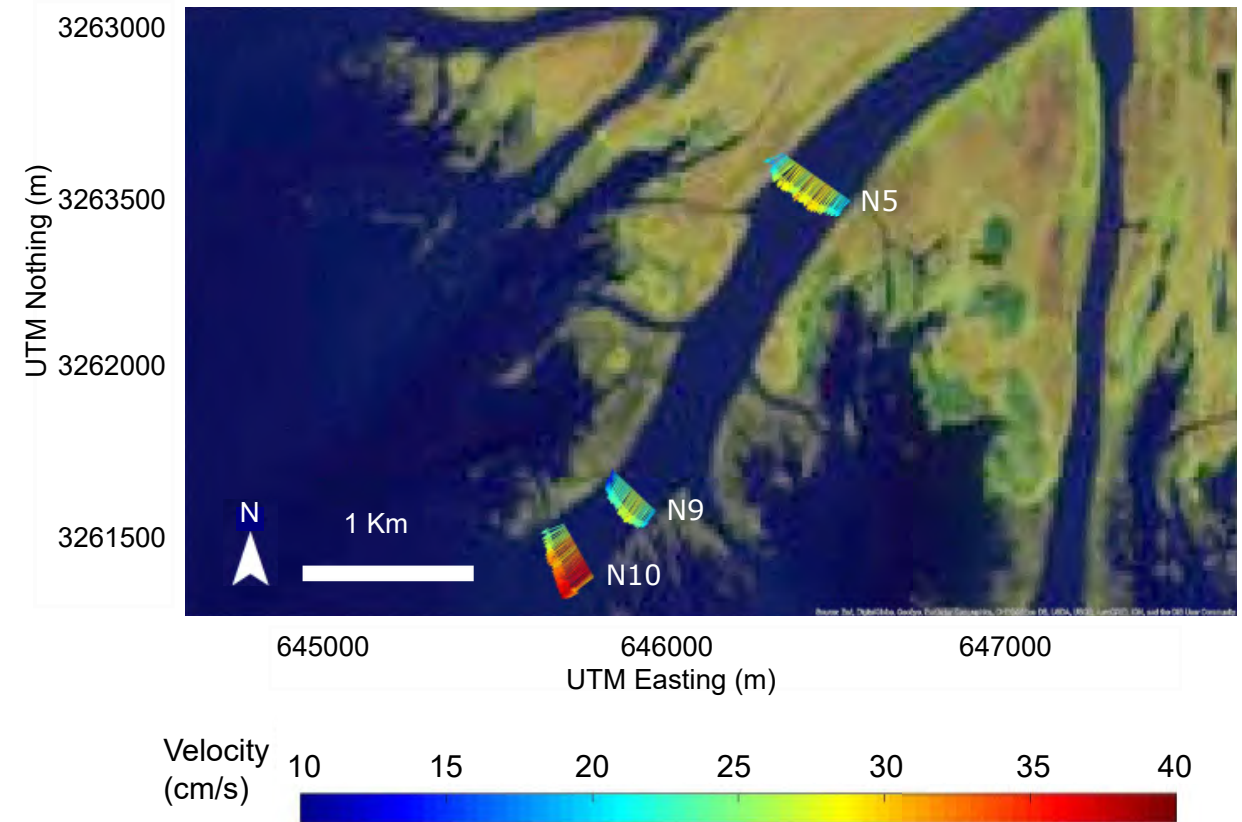

Figure 9. Depth-averaged velocity vectors along the Gadwall Pass for (a) campaign 3, rising tide, 13 September 2019, and (b) campaign 4, falling tide, 14 September 2019. 
In campaign 3, the backscatter intensity dropped at the location of transect N9 (Fig. 10). Also at N9 the backscatter is higher $(\sim 7 \mathrm{~dB})$ over the subaqueous levees than the main channel. Additionally, this transect had 30\% discharge loss relative to N5 due to lateral outflow (Fig. S2).

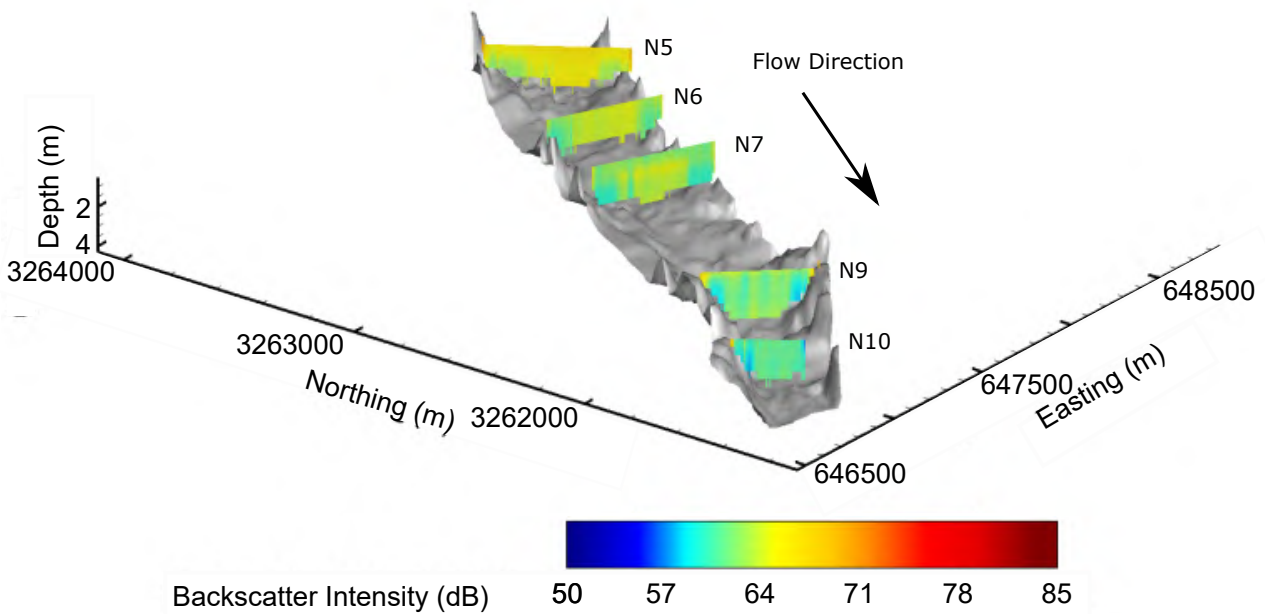

Figure 10. Backscatter intensity data for the Unchannelized Outflow during campaign 1 (rising tide, 13 September 2019).

\section{Flow Structure}

During the UO outflow surveys on campaigns 3 and 4, no significantly coherent secondary structures were observed at any of the transects (Fig. 11a and b). During rising tide, there's a hint of a loosely coherent counter-clockwise rotating structure in the middle of transect N9 (Fig. 11a), although it was not observed during falling tide (Fig. 11b). Therefore, tides seem to have an effect on the secondary structures in the unchannelized zone that may also be driven by modulation of the water-level gradient. Minimal turbulent exchange in this unconfined part of the delta has also been previously reported. Thus the incoherence of flow structures is expected as also the channel discharge was considerably lower. The transverse flow was observed to be directed from the right bank to the left bank (looking downstream) during both campaigns 3 and 4 (Fig. S4). 
(a) N9 Rising Tide

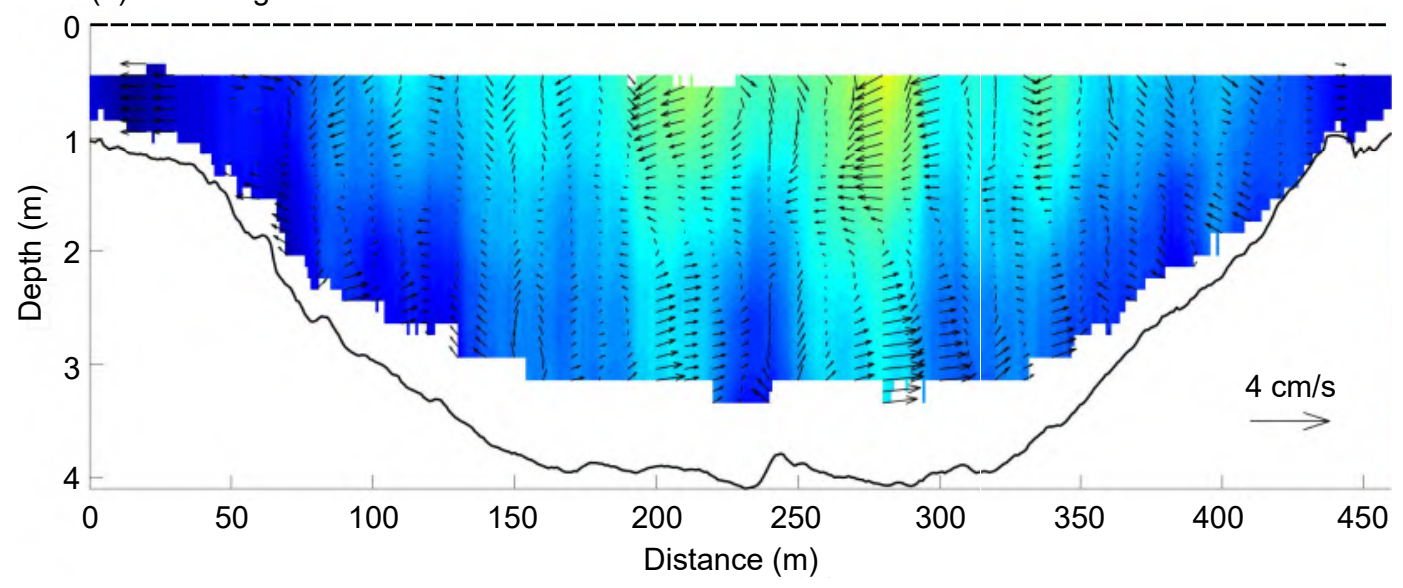

(b) N9 Falling Tide

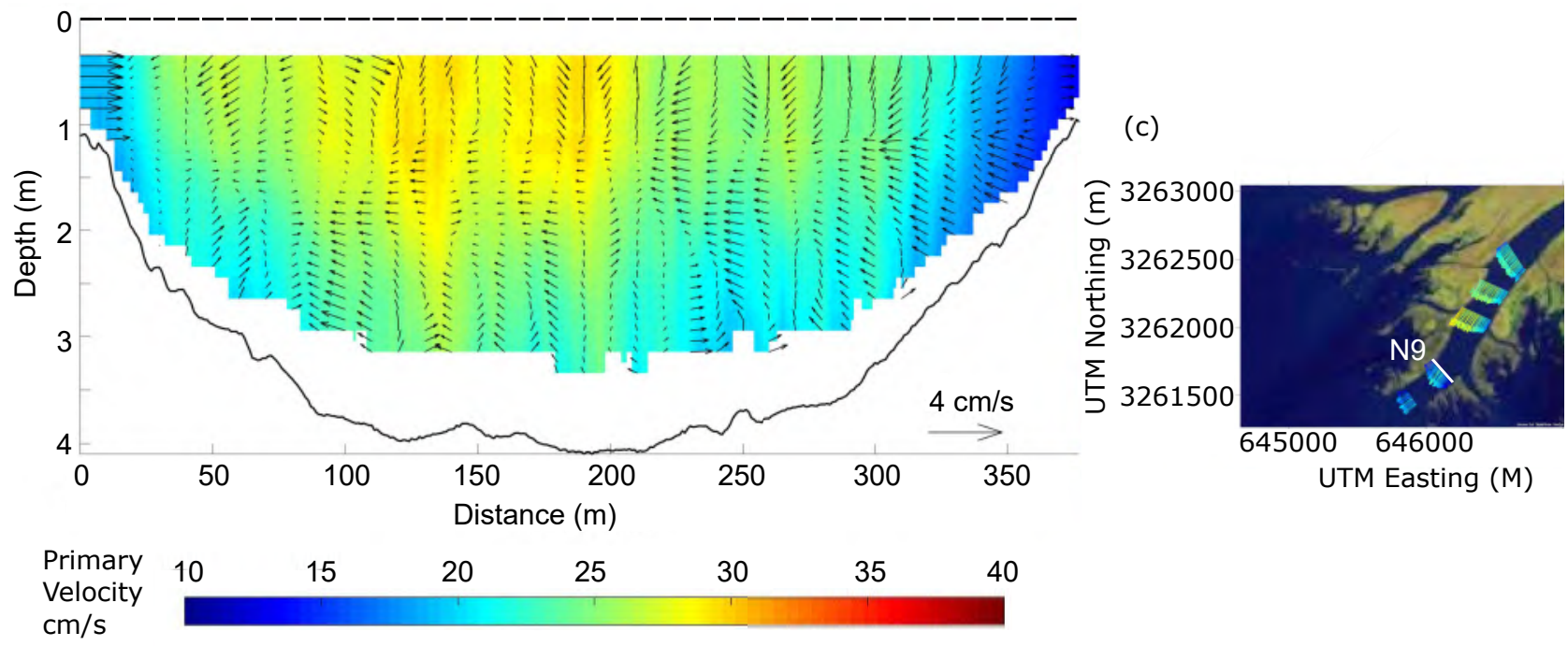

Figure 11. Flow structure at transect N9, downstream part of Gadwall Pass (looking downstream). The contour shows the primary velocity and the secondary velocities in Rozovskii reference frame are shown by arrows for (a) campaign 3 (rising tide, 13 September 2019) and (b) campaign 4 (falling tide, 14 September, 2019) (c) Location of the transect. 


\section{Discussion}

The results from this study provide an insight into the lateral outflow process in deltaic systems and how it impacts the three-dimensional flow structure, sediment transport mechanisms, and delta morphology. Coffey and Shaw (2017) suggested that lateral outflow is a vital mechanism for delta growth and maintenance. Besides, flow loss through lateral outflow is also responsible for modulating the velocity and sediment transport trends in the lowermost reach of a river (Esposito et al., 2020). Accordingly, lateral outflow is likely a salient feature of prograding deltas, making the lateral outflow observed at WLD more of the norm rather than the exception. Therefore, results from this study and the flow features described previously in the literature, all suggest that the findings can be extended to the lateral outflow conditions in other deltas to understand natural land building processes with implications for sediment diversion.

\section{How does lateral outflow affect the three-dimensional flow structure within delta distributary channels?}

Three-dimensional flow structure data from the channelized outflow sites (Fig. 6, $7,8)$ indicate formation of the unique secondary circulation cells induced by lateral outflow. A coherent counter-clockwise rotating cell was observed inside the lateral channel (Fig. 8a and b) along with a clockwise rotating cell at the depression zone of transect M4 (Fig. 6b). Although the system studied here is discordant (bed elevation difference between the main and lateral channels), the circulation pattern of these two cells matches the previous observations made on non-discordant $90^{\circ}$ diversions (Neary et al., 1999; Herrero et al., 2015; Dutta et al., 2017). The coherent counter-clockwise rotating helical cell observed in the upstream separation zone on the right bank (Fig. 6a and c) suggests that the influence of channelized outflow extends even upstream as far as $120 \mathrm{~m}$ (half channel width) from the lateral channel mouth. These circulation cells are fueled by the imbalance between transverse pressure gradient, shear, and centrifugal forces (Neary \& Odgaard, 1995). We hypothesize that the strength of these cells for a discordant system depends on the momentum flux effectively removed by the lateral channel from the main flow similar to the interpretation made by Herrero et al. (2015) in case of a non-discordant diversion. The flow structures observed for channelized outflow were not appreciably altered by tides, but the depth-averaged velocity demonstrated a significant change (Fig. 4).

The bathymetry for transects M4 and M5 (Fig. 3) indicates a depression zone on the right bank and resembles a compound channel with a floodplain. The depression zone observed (Fig. 6b and 7) was reported previously by Herrero et al. (2015) for a similar lateral outflow configuration and they suggested that sedimentation occurs in the depression zone below a threshold momentum flux ratio $\left(M_{r}\right)$ of 0.04 . For campaign 1 and $2, M_{r}$ for the CO system was 0.04 and 0.03 respectively (Table 1 ) suggesting sedimentation may have occurred during both surveys. Varying $M_{r}$ with discharge, tides, and storms may modify the zone as temporally erosional or depositional. Although, the hydrodynamic parameters suggest deposition at the depression zone during survey times, the data is not enough to predict the trend of long term erosion or deposition.

At transect M4 and M5, water was observed to enter the channel from the island, which altered the flow structure patterns. At transect M5 (Fig. 7), a small crevasse on the right bank induced a counter-clockwise rotating cell in the right bank of the main channel (Fig. 7a) during campaign 1. The circulation cell was not present during campaign 2 and only one clockwise rotating secondary structure could be identified in the main channel (Fig. 7c). The transverse velocity vectors (Fig. 7d) indicate a large transverse current from the floodplain to the channel on campaign 2 compared to the smaller flow during campaign 1 (Fig. 7b). A similar observation was made at transect M4 (Fig. S3) showing a larger transverse current moving into the main channel during rising tide (Fig. S3d) but the circulation direction remained unchanged during both campaigns (Fig. 
S3a and c). It is difficult to assess the effect of transverse current from M4 because of that but the non existence of the crevasse induced counter-clockwise circulation at M5 during rising tide (Fig. 7c) supports the observation by Proust and Nikora (2019) suggesting if the transverse flow direction is from the floodplain to the channel, the secondary cells merge into a single cell in the main channel. For UO, such observation could not be made (Fig. 11 and S4) perhaps because of the significantly lower flow velocity. Additionally, the channel-wide clockwise circulation observed in four of the transects in the the main channel (Fig. 6 and 7 ) is likely to be the very large scale motion (VLSM) described by Proust and Nikora (2019). Though, the interaction between VLSM and lateral outflow induced secondary circulation remains unclear, it can be hypothesized that the presence of a channel or crevasse causing lateral outflow may influence the spatial extent of such VLSM cells.

In agreement with the previous $90^{\circ}$ open channel diversion studies (Neary et al., 1999; Herrero et al., 2015; Dutta et al., 2017), a shallow elongated bar was observed inside the lateral channel (Fig. 3). The associated counter-clockwise rotating secondary circulation (Fig. 8) observed at transects L3 and L4, may scour the channel bed in the left bank, entrain and carry the scoured sediment near the right bank, where the flow is slower (Fig. 4). This mechanism may lead to the formation of the elongated shallow bar in the reduced velocity zone on the right bank. In addition, we observed this coherent cell breaking down after a distance of 2.6-4.5 lateral channel width into multiple cells (Fig. 8c). This distance may depend upon the momentum flux available inside the lateral channel. Although no shallow bar was observed on the opposite bank of the lateral channel, in contrast to the results from non-discordant diversion modeling efforts (Bulle, 1926; Neary et al., 1999). This may be attributed to the environmental set up of the lateral channel or to the presence of a strong lateral flow through a crevasse on the opposite bank of the lateral channel.

\section{Does lateral outflow impact the mechanism of sediment transport from the channel to the island?}

The effect of the outflow induced circulation cells in the CO zone on transport process can be inferred from the backscatter intensity data from the surveys (Fig. 5). Backscatter intensity has been used previously as an indicator of suspended sediment concentration in a system (Dinehart \& Burau, 2005). The increased intensity in the separation zone and inside the lateral channel (Fig. 5), can be interpreted as a representation of interaction between the outflow induced circulation cells and the suspended sediment particles. The intensity may increase if the lateral channel or crevasse becomes narrower and the circulation it induces becomes stronger as a result of increasing $M_{r}^{\prime}$. From the calculation of settling velocity in section 2.4 , it was found that for the median grain size of $106 \mu \mathrm{m}$ (Shaw et al., 2013) in WLD, the settling velocity was $0.8 \mathrm{~cm} / \mathrm{s}$. The counterclockwise rotating coherent circulation cell velocity for the channelized outflow, which was $2-4 \mathrm{~cm} / \mathrm{s}$ (Fig. 6a), is an order of magnitude greater than the settling velocity and thus may entrain the median sized particles, keep them suspended, and transport them inside the lateral channel. According to this calculation, this cell may effectively entrain and transport particles of grain size up to $200 \mu \mathrm{m}$.

Though flow structures for unchannelized outflow did not show any significant coherent circulation during the surveys, the backscatter intensity suggests (Fig. 10) sediment being transported to the islands or falling out of suspension. Shaw et al. (2016) suggested from their flow pattern study that the lateral turbulent mixing from the unstable flow is minimal in the subaqueous delta and Hiatt and Passalacqua (2017) showed that the unconfined flow regime of the delta has a gradient of water-level between the channel and the island. Therefore, the flow structure data of unchannelized outflow is in agreement with the conclusion from Shaw et al. (2016). The existence of a water-level gradient along with the gently sloped, widespread levees in the subaqueous delta sug- 
gests that the sediment transport in this part of the delta is mostly advective (Adams et al., 2004; Shaw et al., 2016). However, after a major flood, the levee morphology in such areas was observed to be shifted towards being narrow and steep (Bevington \& Twilley, 2018). We anticipate that during floods the dominant sediment transport mechanism shifts to turbulent diffusion (Adams et al., 2004) as then there is enough lateral momentum available to form secondary coherent structures (Kelvin-Helmholtz type coherent structures or KHCS and Secondary currents or SC), but there is not sufficient data to address them in this study. In such cases, KHCS and SC may become the dominant control over the transport of sediment to the islands and construct steeply sloped levees as suggested by the observations of Bevington and Twilley (2018) at WLD following the 2011 flood. Existence of an outflow momentum flux ratio threshold is thus proposed here for which the transport mechanism shifts from advective to turbulent diffusion. From the calculated $M_{r}^{\prime}$ for both CO and UO surveys, we hypothesize that the threshold ratio required for the switch, lies in between $0.211 \mathrm{~km}^{-1}$ and $0.375 \mathrm{~km}^{-1}$.

Existence of shear-induced Kelvin Helmholtz type horizontal coherent structures can be a major control over the lateral momentum exchange (van Prooijen et al., 2005; Truong et al., 2019; Proust \& Nikora, 2019), but it was not possible to capture their presence with the current field measurements. Moreover, the secondary circulation cells may influence the transport effect of such horizontal structures. The existence of such cells can be of prime importance for the transport of sediment, particles, and nutrients into the islands through channelized and unchannelized outflow.

The effect of vegetation was integrated in the field data, and it is currently not considered independently, though vegetation likely has a significant impact on flow structure, transport, and retention of sediment (Nepf \& Vivoni, 2000; Nepf, 2012; Olliver et al., 2020). Therefore, the threshold outflow momentum flux ratio can vary from what is suggested here based on the presence of vegetation. A detailed numerical simulation is required to come to a more precise limit for the threshold.

\section{A Conceptual Model of Flow Structure and Sediment Transport Influ- enced by Lateral Outflow}

Based on these findings, a conceptual model is developed connecting the lateral outflow induced flow structures with the sediment transport mechanisms in a deltaic distributary system. The conceptual model can be parsed into two scenarios based on the outflow momentum flux ratio threshold.

\section{Channelized Outflow}

During non-flood periods, the discharge and velocity through the distributary channels are comparatively small. The discordant lateral channels receive a smaller amount of discharge and often, the sediment transport occurs solely through advection and controlled by the water-level gradient between the main channel and lateral channel. During high flow periods, if the channelized outflow system reaches the threshold $M_{r}^{\prime}$, a counterclockwise rotating helical SC (Fig. 12) develops near the bank upstream (for right-sided channels, right bank). With sufficient helical velocity, this cell will entrain and transport suspended sediment from the separation zone into the lateral channel. In the main channel there may already exist VLSM (Fig. 12), which is either amplified or reduced by the SC. Additionally, the velocity difference between the main channel and lateral channel may induce shear induced KHCS at the lateral channel entrance contributing to the momentum transfer from and to the main channel. Downstream of the lateral channel, a clockwise rotating SC forms in the depression zone. A helical SC is generated inside the lateral channel rotating counterclockwise (Fig. 12) (for lateral channels on the right bank, looking downstream, clockwise for the left bank lateral channels), and the flow inside is separated into two zones. The left bank of the lateral channel carries the larger part of 


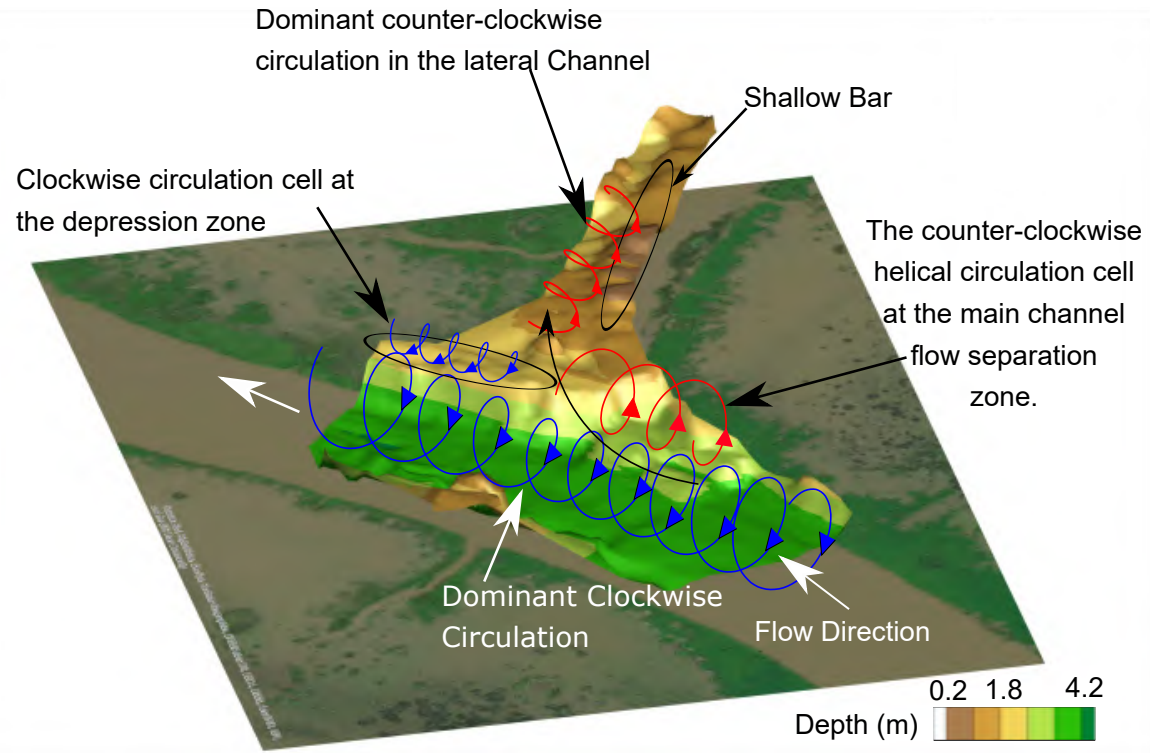

Figure 12. Conceptual figure of channelized lateral outflow

the flow with higher velocity and thus scours the left bank. The scoured sediment are carried by the circulation cell and deposited near the right bank of the channel, forming a shallow bar (for left bank lateral channels, a clockwise circulation cell will deposit sediment near the left bank scouring the right side of the channel). The counterclockwise cell inside the lateral channel gradually breaks down with distance and the thalweg shifts from left to the center of the channel, sediment deposition occurs, and the depth gradually decreases.

\section{Unchannelized Outflow}

For the unconfined zone of the delta, turbulent activity is minimal during non-flood discharges. A water-level gradient exists between the distributary channels and the inundated islands (Hiatt \& Passalacqua, 2017). Sediment transport in the unconfined parts of the delta is dominated by advection during regular flow periods. Sediment transport incorporated with the outflow process builds natural levees on the island edge. The levees formed by advection are gently sloped and widespread along the island edge (Fig. 13a). When floods occur, the distributary channels carry enough momentum to induce coherent secondary structures at the channel island interface. Once the $M_{r}^{\prime}$ threshold is reached, and helical circulation cells (SC) start to form close to the banks. The velocity gradient between the main channel and islands acts to establish KHCS, which contributes significantly towards the momentum transfer between the channel and inundated islands. In this way, SC and KHCS become the dominant sediment transport controls during flood periods. Thus, with sufficient momentum, transport mechanism shifts from advection to turbulent diffusion and narrow, steeper natural levee structures are formed (Fig. 13b). The presence of vegetation may influence the effect of transport mechanism as sediment retention is related to vegetation pattern (Temmerman et al., 2005). After the flood, the transport mechanism again shifts back to advection, and low-gradient levees are favored. The number of secondary circulation cells along the bank is difficult to assess from the current field data and for that reason, only one cell near each bank is shown in the conceptual figure (Fig. 13b). 
(a)

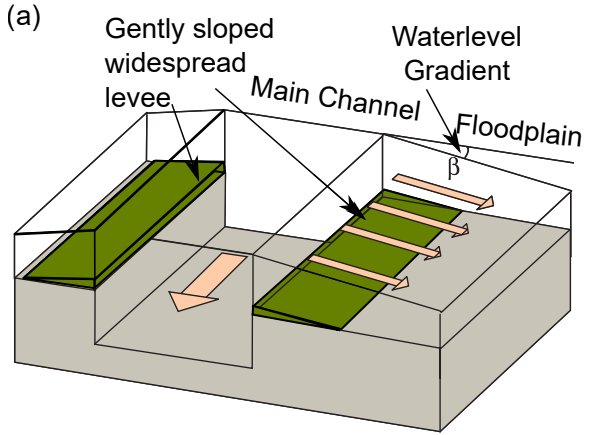

(b)

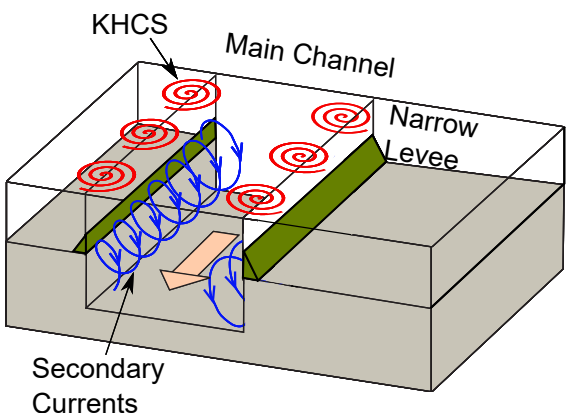

Figure 13. Conceptual figure of sediment transport during unchannelized lateral outflow through (a) advection (low flow), (b) turbulent diffusion (high flow).

\section{Conclusions}

This study aimed to understand the effect of lateral outflow on the three-dimensional flow structure in the distributary channels of a river dominated delta. Lateral outflow is critical for deltaic maintenance, growth, and morphodynamic evolution. Thus, studying flow structure in a deltaic system experiencing lateral outflow can provide valuable insight into the natural land-building processes, which will be helpful to maximize the result of ongoing restoration efforts. Accordingly, the flow structure in two distributary channels subject to two different types of lateral outflow at Wax Lake Delta (WLD) was studied here.

Hydrographic surveys were performed using an acoustic Doppler current profiler (ADCP) to map the flow structure and bathymetry of two sites typifying channelized and unchannelized outflow zones in a prograding river delta. A conceptual model for the flow structure and a transport mechanism framework was developed. In the channelized outflow site, four coherent secondary structures were observed, whereas no significant coherent secondary circulations were observed for the site with unchannelized outflow. Though tides had a marginal effect on secondary flow structures at the channelized outflow site, tides did alter secondary flow structures in the unchannelized outflow site.

Patterns in bed morphology were linked to the coherent circulation cells. Backscatter intensity data from the survey were used to qualitatively assess sediment transport pathways related to the observed secondary flows. In addition, a calculation of particle settling velocity at WLD showed that the observed outflow induced coherent circulation cells were capable of carrying suspended particles up to $200 \mu \mathrm{m}$ into the lateral channel.

Flow structure observations for unchannelized outflow along with the observation by previous literature suggest advective sediment transport from the channels to the islands in this region during periods of low flow. The effect of outflow on flow structure here is minimal as the momentum transfer occurs over a large distance, unlike the smaller outflow length in case of channelized outflow. During floods, with sufficient lateral momentum, a shift of transport mechanism to turbulent diffusion may occur leading to a change in levee morphology. A framework for this shift and transport is suggested based on a hypothesized threshold outflow momentum flux ratio that lies in between $0.211 \mathrm{~km}^{-1}$ and $0.375 \mathrm{~km}^{-1}$ above which horizontal and vertical secondary flow structures may form in the distributary channels, and impact sediment transport. Below the threshold, the water-level gradient controls the advective transport of sediment to the islands. 
The results from this study suggests that the maximum grain size of suspended sediments carried inside the lateral channel may depend on the strength of the secondary circulation cell in the upstream separation zone which is dependent upon the outflow momentum flux ratio. Patterns in three dimensional flow structure may help understand the morphology and evolution of discordant bifurcations and crevasses. Additionally, the lateral momentum flux ratio introduced here may help predict the size of sediment available for transport either through channelized or unchannelized outflow, which has implications for the operation and evaluation of sediment diversions intended for coastal restoration.

\section{Acknowledgments}

This material is based on work supported by the College of Coast and Environment, Louisiana State University. The authors would like to thank Kehui (Kevin) Xu for his continued collaboration and feedback.

\section{References}

Adams, P. N., Slingerland, R. L., \& Smith, N. D. (2004). Variations in natural levee morphology in anastomosed channel flood plain complexes. Geomorphology, 61 (1-2), 127-142. doi: 10.1016/j.geomorph.2003.10.005

Azevedo, R., Roja-Solórzano, L. R., \& Leal, J. B. (2017). Turbulent structures, integral length scale and turbulent kinetic energy (TKE) dissipation rate in compound channel flow. Flow Measurement and Instrumentation, 57, 10-19. doi: 10.1016/j.flowmeasinst.2017.08.009

Bevington, A. E., \& Twilley, R. R. (2018). Island edge morphodynamics along a chronosequence in a prograding deltaic floodplain wetland. Journal of Coastal Research, 344, 806-817. doi: 10.2112/jcoastres-d-17-00074.1

Branß, T., Dittrich, A., \& Núñez-González, F. (2016). Reproducing natural levee formation in an experimental flume. In River flow 2016. CRC Press. doi: 10 $.1201 / 9781315644479-178$

Bulle, H. (1926). Untersuchungen über die geschiebeableitung bei der spaltung von wasserläufen: Modellversuche aus dem flussbaulaboratorium der technischen hochschule zu karlsruhe. VDI-Verlag.

Chowdhury, M. K. (2020). akifayath/teledyne-adcp-tilt-correction: Adcp tilt correction. Zenodo. doi: 10.5281/ZENODO.3759971

Citerone, V. (2016). Enhancing gas transfer at an air-water interface through strengthened secondary flows motivated by algal biofuel production. Retrieved from https://ecommons. cornell. edu/handle/1813/44408

Coffey, T. S., \& Shaw, J. B. (2017). Congruent bifurcation angles in river delta and tributary channel networks. Geophysical Research Letters, n/a-n/a. (2017GL074873) doi: 10.1002/2017GL074873

Cokljat, D., \& Younis, B. A. (1995, February). Second-order closure study of openchannel flows. Journal of Hydraulic Engineering, 121(2), 94-107. doi: 10.1061/ (asce)0733-9429(1995)121:2(94)

CPRA. (2017). Restoration authority of louisiana. louisiana's comprehensive master plan for a sustainable coast. Coastal Protection and Restoration Authority [Internet].

Day, J. W., Britsch, L. D., Hawes, S. R., Shaffer, G. P., Reed, D. J., \& Cahoon, D. (2000). Pattern and process of land loss in the mississippi delta: A spatial and temporal analysis of wetland habitat change. Estuaries, 23(4), 425. doi: $10.2307 / 1353136$

Dietrich, W. E. (1982). Settling velocity of natural particles. Water Resources Research, 18(6), 1615-1626. doi: 10.1029/wr018i006p01615

Dinehart, R., \& Burau, J. (2005). Repeated surveys by acoustic doppler current 
profiler for flow and sediment dynamics in a tidal river. Journal of Hydrology, 314 (1-4), 1-21. doi: 10.1016/j.jhydrol.2005.03.019

Dutta, S., Fischer, P., \& Garcia, M. H. (2016). Large eddy simulation (les) of flow and bedload transport at an idealized 90-degree diversion: Insight into bulle effect. River Flow 2016: Iowa City, USA, July 11-14, 2016, 101.

Dutta, S., Wang, D., Tassi, P., \& Garcia, M. H. (2017). Three-dimensional numerical modeling of the bulle effect: the nonlinear distribution of near-bed sediment at fluvial diversions. Earth Surface Processes and Landforms, 42(14), 2322-2337. doi: 10.1002/esp.4186

Dwivedi, A., Melville, B. W., Shamseldin, A. Y., \& Guha, T. K. (2011). Flow structures and hydrodynamic force during sediment entrainment. Water Resources Research, 47(1). doi: 10.1029/2010wr009089

Edmonds, D. A., Paola, C., Hoyal, D. C. J. D., \& Sheets, B. A. (2011). Quantitative metrics that describe river deltas and their channel networks. Journal of Geophysical Research, 116(F4). doi: 10.1029/2010jf001955

Engel, F. L., \& Rhoads, B. L. (2017). Velocity profiles and the structure of turbulence at the outer bank of a compound meander bend. Geomorphology, 295, 191-201. doi: 10.1016/j.geomorph.2017.06.018

Esposito, C. R., Georgiou, I. Y., \& Straub, K. M. (2020). Flow loss in deltaic distributaries: Impacts on channel hydraulics, morphology and stability. Water Resources Research. doi: 10.1029/2019wr026463

Frothingham, K. M., \& Rhoads, B. L. (2003). Three-dimensional flow structure and channel change in an asymmetrical compound meander loop, embarras river, illinois. Earth Surface Processes and Landforms: The Journal of the British Geomorphological Research Group, 28(6), 625-644.

Hardy, R. J., Lane, S. N., \& Yu, D. (2011). Flow structures at an idealized bifurcation: a numerical experiment. Earth Surface Processes and Landforms, 36(15), 2083-2096. doi: 10.1002/esp.2235

Herrero, A., Bateman, A., \& Medina, V. (2015). Water flow and sediment transport in a $90^{\circ}$ channel diversion: an experimental study. Journal of Hydraulic Research, 53(2), 253-263. doi: 10.1080/00221686.2014.989457

Hiatt, M., \& Passalacqua, P. (2015). Hydrological connectivity in river deltas: The first-order importance of channel-island exchange. Water Resour. Res., 51, 2264-2282. doi: 10.1002/2014WR016149

Hiatt, M., \& Passalacqua, P. (2017). What controls the transition from confined to unconfined flow? analysis of hydraulics in a coastal river delta. Journal of Hydraulic Engineering, 143(6), 03117003. doi: 10.1061/(asce)hy.1943-7900 .0001309

Kang, H., \& Choi, S.-U. (2006). Turbulence modeling of compound open-channel flows with and without vegetation on the floodplain using the reynolds stress model. Advances in Water Resources, 29(11), 1650-1664. doi: 10.1016/j.advwatres.2005.12.004

Kim, W., Mohrig, D., Twilley, R., Paola, C., \& Parker, G. (2009). $\quad$ Is it feasible to build new land in the mississippi river delta? Eos, Transactions American Geophysical Union, 90(42), 373-374. doi: 10.1029/2009eo420001

Konsoer, K. M., Rhoads, B. L., Best, J. L., Langendoen, E. J., Abad, J. D., Parsons, D. R., \& Garcia, M. H. (2016). Three-dimensional flow structure and bed morphology in large elongate meander loops with different outer bank roughness characteristics. Water Resources Research, 52(12), 9621-9641. doi: 10.1002/2016wr019040

Lane, S. N., Bradbrook, K., Richards, K., Biron, P., \& Roy, A. (2000). Secondary circulation cells in river channel confluences: measurement artefacts or coherent flow structures? Hydrological Processes, 14 (11-12), 2047-2071.

Marra, W. A., Parsons, D. R., Kleinhans, M. G., Keevil, G. M., \& Thomas, R. E. (2014). Near-bed and surface flow division patterns in experimen- 
tal river bifurcations.

Water Resources Research, 50(2), 1506-1530.

doi: 10.1002/2013wr014215

Michelazzo, G., Minatti, L., Paris, E., \& Solari, L. (2016). Side weir flow on a movable bed. Journal of Hydraulic Engineering, 142(6), 04016007. doi: 10.1061/ (ASCE)HY.1943-7900.0001128

Miyawaki, S., Constantinescu, G., Rhoads, B., \& Sukhodolov, A. (2010). Changes in three-dimensional flow structure at a river confluence with changes in momentum ratio. In River flow (Vol. 2010, pp. 225-232).

Mueller, D., Wagner, C., Rehmel, M., Oberg, K., \& Rainville, F. (2013). Measuring discharge with acoustic Doppler current profilers from a moving boat (ver. 2.0, December 2013): US Geological Survey Techniques and Methods, book 3, chap. A22., 95. (available at http://pubs.usgs.gov/tm3a22/)

Naot, D., Nezu, I., \& Nakagawa, H. (1993). Hydrodynamic behavior of compound rectangular open channels. Journal of Hydraulic Engineering, 119(3), 390-408. doi: 10.1061/(asce)0733-9429(1993)119:3(390)

Naot, D., Nezu, I., \& Nakagawa, H. (1996). Hydrodynamic behavior of partly vegetated open channels. Journal of Hydraulic Engineering, 122(11), 625-633. doi: 10.1061/(asce)0733-9429(1996)122:11(625)

Neary, V. S., \& Odgaard, A. J. (1993). Three-dimensional flow structure at openchannel diversions. Journal of Hydraulic Engineering, 119(11), 1223-1230.

Neary, V. S., \& Odgaard, A. J. (1995). Closure to "three-dimensional flow structure at open-channel diversions" by vincent s. neary and a. jacob odgaard. Journal of Hydraulic Engineering, 121(1), 88-90.

Neary, V. S., Sotiropoulos, F., \& Odgaard, A. J. (1999). Three-dimensional numerical model of lateral-intake inflows. Journal of Hydraulic Engineering, 125(2), 126-140. doi: 10.1061/(asce)0733-9429(1999)125:2(126)

Nepf, H. M. (2012). Hydrodynamics of vegetated channels. Journal of Hydraulic Research, 50(3), 262-279. doi: 10.1080/00221686.2012.696559

Nepf, H. M., \& Vivoni, E. R. (2000). Flow structure in depth-limited, vegetated flow. Journal of Geophysical Research: Oceans, 105(C12), 28547-28557. doi: 10.1029/2000JC900145

Nezu, I., \& Onitsuka, K. (2001). Turbulent structures in partly vegetated openchannel flows with LDA and PI v measurements. Journal of Hydraulic Research, 39(6), 629-642. doi: 10.1080/00221686.2001.9628292

Olliver, E. A., Edmonds, D. A., \& Shaw, J. B. (2020). Influence of floods, tides, and vegetation on sediment retention in wax lake delta, louisiana, USA. Journal of Geophysical Research: Earth Surface, 125(1). doi: 10.1029/2019jf005316

Pal, S., Lee, T. R., \& Clark, N. E. (2020). The 2019 mississippi and missouri river flooding and its impact on atmospheric boundary layer dynamics. Geophysical Research Letters, 47(6). doi: 10.1029/2019gl086933

Paola, C., Twilley, R. R., Edmonds, D. A., Kim, W., Mohrig, D., Parker, G., ... Voller, V. R. (2011, January). Natural processes in delta restoration: Application to the mississippi delta. Annual Review of Marine Science, 3(1), 67-91. doi: 10.1146/annurev-marine-120709-142856

Paris, E., Solari, L., \& Bechi, G. (2012). Applicability of the De Marchi hypothesis for side weir flow in the case of movable beds. Journal of Hydraulic Engineering, 138(7), 653-656. doi: 10.1061/(ASCE)HY.1943-7900.0000566

Parsons, D. R., Jackson, P. R., Czuba, J. A., Engel, F. L., Rhoads, B. L., Oberg, K. A., .. Riley, J. D. (2013). Velocity mapping toolbox (VMT): a processing and visualization suite for moving-vessel ADCP measurements. Earth Surface Processes and Landforms, 38(11), 1244-1260. doi: 10.1002/esp.3367

Passalacqua, P. (2017). The delta connectome: A network-based framework for studying connectivity in river deltas. Geomorphology, 277, 50-62. doi: 10 $.1016 /$ j.geomorph.2016.04.001

Proust, S., \& Nikora, V. I. (2019). Compound open-channel flows: effects of trans- 
verse currents on the flow structure. Journal of Fluid Mechanics, 885. doi: 10 $.1017 / \mathrm{jfm} .2019 .973$

Ramamurthy, A. S., Qu, J., \& Vo, D. (2007). Numerical and experimental study of dividing open-channel flows. Journal of Hydraulic Engineering, 133(10), 11351144. doi: $10.1061 /($ asce) $0733-9429(2007) 133: 10(1135)$

Rennie, C. D., \& Church, M. (2010). Mapping spatial distributions and uncertainty of water and sediment flux in a large gravel bed river reach using an acoustic doppler current profiler. Journal of Geophysical Research, 115(F3). doi: $10.1029 / 2009 j f 001556$

Rhoads, B. L., \& Kenworthy, S. T. (1998). Time-averaged flow structure in the central region of a stream confluence. Earth Surface Processes and Landforms: The Journal of the British Geomorphological Group, 23(2), 171-191.

Rhoads, B. L., \& Sukhodolov, A. N. (2001). Field investigation of threedimensional flow structure at stream confluences: 1. thermal mixing and time-averaged velocities. Water Resources Research, 37(9), 2393-2410. doi: 10.1029/2001wr000316

Roberts, H. (1998). Delta switching: early responses to the atchafalaya river diversion. Journal of Coastal Research, $14(3)$.

Roberts, H., Coleman, J., Bentley, S., \& Walker, N. (2003). An embryonic major delta lobe: A new generation of delta studies in the atchafalaya-wax lake delta system.

Roberts, H., Walker, N., Cunningham, R., Kemp, G., \& Majersky, S. (1997). Evolution of sedimentary architecture and surface morphology: Atchafalaya and wax lake deltas, louisiana (1973-1994).

Rosier, B., Boillat, J.-L., \& Schleiss, A. J. (2011). Influence of lateral water withdrawal on bed form geometry in a channel. Journal of Hydraulic Engineering, 137(12), 1668-1675. doi: 10.1061/(asce)hy.1943-7900.0000472

Rozovskii, I. (1957). Flow of water in bends of open channels (in russian), 233 pp. Acad. of Sci. of the Ukrainian SSR, Kiev.(English translation, Isr. Program for Sci. Transl., Jerusalem, 1961.).

Serres, B. D., Roy, A. G., Biron, P. M., \& Best, J. L. (1999). Three-dimensional structure of flow at a confluence of river channels with discordant beds. Geomorphology, 26 (4), 313-335. doi: 10.1016/s0169-555x(98)00064-6

Shaw, J., Estep, J. D., Whaling, A. R., Sanks, K. M., \& Edmonds, D. A. (2018). Measuring subaqueous progradation of the wax lake delta with a model of flow direction divergence. Earth Surface Dynamics, 6(4), 1155-1168. doi: 10.5194/esurf-6-1155-2018

Shaw, J., Mohrig, D., \& Wagner, R. W. (2016). Flow patterns and morphology of a prograding river delta. Journal of Geophysical Research: Earth Surface, 121 (2), 372-391. doi: 10.1002/2015JF003570

Shaw, J., Mohrig, D., \& Whitman, S. (2013). The morphology and evolution of channels on the Wax Lake Delta, Louisiana, USA. J. Geophys. Res.: Earth Surf., 108. doi: 10.1002/jgrf.20123

Shiono, K., \& Knight, D. W. (1991). Turbulent open-channel flows with variable depth across the channel. Journal of Fluid Mechanics, 222(-1), 617. doi: 10 $.1017 / \mathrm{s} 0022112091001246$

Sofialidis, D., \& Prinos, P. (1999). Numerical study of momentum exchange in compound open channel flow. Journal of Hydraulic Engineering, 125(2), 152-165. doi: 10.1061/(asce)0733-9429(1999)125:2(152)

Sukhodolov, A. N. (2012). Structure of turbulent flow in a meander bend of a lowland river. Water Resources Research, 48(1). doi: 10.1029/2011wr010765

Szupiany, R. N., Amsler, M. L., Best, J. L., \& Parsons, D. R. ～(2007). Comparison of fixed- and moving-vessel flow measurements with an $\mathrm{aDp}$ in a large river. Journal of Hydraulic Engineering, 133(12), 1299-1309. doi: 10.1061/(asce)0733-9429(2007)133:12(1299) 
Szupiany, R. N., Amsler, M. L., Parsons, D. R., \& Best, J. L. (2009). Morphology, flow structure, and suspended bed sediment transport at two large braid-bar confluences. Water Resources Research, 45(5). doi: 10.1029/2008wr007428

Teledyne, R. I. (2010). Adcp coordinate transformation: formulas and calculations. TELEDYNE RD INSTRUMENTS, Technical manual.

Teledyne, R. I. (2017). Riverpro \& riopro adcp guide [Computer software manual]. Temmerman, S., Bouma, T. J., Govers, G., Wang, Z. B., De Vries, M., \& Herman, P. (2005). Impact of vegetation on flow routing and sedimentation patterns: Three-dimensional modeling for a tidal marsh. Journal of Geophysical Research: Earth Surface, 110(F4). doi: 10.1029/2005jf000301

Temmerman, S., \& Kirwan, M. L. (2015). Building land with a rising sea. Science, 349(6248), 588-589. doi: 10.1126/science.aac8312

Temmerman, S., Meire, P., Bouma, T. J., Herman, P. M. J., Ysebaert, T., \& Vriend, H. J. D. (2013). Ecosystem-based coastal defence in the face of global change. Nature, 504(7478), 79-83. doi: 10.1038/nature12859

Tominaga, A., \& Nezu, I. (1991). Turbulent structure in compound open-channel flows. Journal of Hydraulic Engineering, 117(1), 21-41. doi: 10.1061/(asce) 0733-9429(1991)117:1(21)

Truong, S. H., Uijttewaal, W. S. J., \& Stive, M. J. F. (2019). Exchange processes induced by large horizontal coherent structures in floodplain vegetated channels. Water Resources Research, 55 (3), 2014-2032. doi: 10.1029/2018wr022954

van Prooijen, B. C., Battjes, J. A., \& Uijttewaal, W. S. J. (2005). Momentum exchange in straight uniform compound channel flow. Journal of Hydraulic Engineering, 131(3), 175-183. doi: 10.1061/(asce)0733-9429(2005)131:3(175)

Venditti, J. G., Rennie, C. D., Bomhof, J., Bradley, R. W., Little, M., \& Church, M. (2014). Flow in bedrock canyons. Nature, 513(7519), 534-537. doi: $10.1038 /$ nature13779

Wellner, R., Beaubouef, R., Van Wagoner, J., Roberts, H., \& Sun, T. (2005). Jetplume depositional bodies - the primary building blocks of wax lake delta.

Yang, K., Cao, S., \& Knight, D. W. (2007). Flow patterns in compound channels with vegetated floodplains. Journal of Hydraulic Engineering, 133(2), 148-159. doi: 10.1061/(asce)0733-9429(2007)133:2(148)

Zeng, Y., Huai, W., \& Zhao, M. (2016). Flow characteristics of rectangular open channels with compound vegetation roughness. Applied Mathematics and Mechanics, 37(3), 341-348. doi: 10.1007/s10483-016-2035-6

Zinger, J. A., Rhoads, B. L., Best, J. L., \& Johnson, K. K. (2013). Flow structure and channel morphodynamics of meander bend chute cutoffs: A case study of the wabash river, USA. Journal of Geophysical Research: Earth Surface, 118(4), 2468-2487. doi: 10.1002/jgrf.20155 